Inorganic \& Coordination Chemistry, Lecture

Designing mono-and multifunctional Solid Catalysts

\section{Avelino Corma}

Instituto de Tecnología Química, UPV-CSIC

Universitat Politécnica de Valencia

Avda. de los Naranjos s/n

46022-Valencia, Spain

In an approach to design selective solid catalysts we start from the knowledge, at the molecular level, of the reaction to be catalyzed. Then hypothesis are made on the nature of the active sites required. At this point we are ready to synthesize solid materials, in where the required active sites are introduced as well defined entities. On top of that the adsorption properties of the solid are taylored to optimize the interactions between reactants, catalyst and products.

Following this methodology will present solid catalysts in where the active sites correspond to well defined transition metal complexes and organocatalysts that are either grafted or structurally builded into solids. In this case, the role of the solid can go beyond a simple support, since it is designed to intervene in the reaction either by stabilizing transition states or by introducing additional active sites.

Well defined single or multiple active sites can also be introduced into crystalline nanoporous materials with controlled adsorption properties, and this allows to perform new acid and redox, one step or multistep reactions.

Finally will show that by depositing metal nanoparticles (Au, Pd, Pt) on proactive supports $\left(\mathrm{CeO}_{2}, \mathrm{Fe}_{2} \mathrm{O}_{3}, \mathrm{MgO}\right.$, hydrotalcites, etc.) we can open new catalytic reaction routes for $\mathrm{C}-\mathrm{C}$ bond formation, oxidations and reductions. These catalytic system allow the design of multifunctional solid catalysts, that are able to carry out multistep process through cascade type reactions that were not possible before.
Inorganic \& Coordination Chemistry, Lecture

Recent Developments in the Applications of Frustrated Lewis Pairs in Hydrogenation and $\mathrm{CO}_{2}$ Reduction

\section{Douglas W. Stephan}

Department of Chemistry University of Toronto, 80 St. George St., Toronto, Ontario, CANADA,

The discovery of "frustrated Lewis pairs" (FLPs) 6 years ago has spawned a great deal of interest in the ability of main group systems to activate small molecules and in the subsequent application in catalysis. ${ }^{1-3}$ Our particular interests have focused on hydrogenation catalysis and on applications for $\mathrm{CO}_{2}$ reduction. In this lecture, we will present recent developments demonstrating FLPs can be used to effect the stoichiometric reduction of aromatic systems ${ }^{4}$ as well as the catalytic reduction of 1,1-disubstituted olefins. In addition, we will also describe recent advances in the use of FLPs for $\mathrm{CO}_{2}$ capture, ${ }^{5-7}$ stoichiometric ${ }^{8}$ and catalytic reduction.

[1] D. W. Stephan, Org. Biomol. Chem. , 2008, 6, 1535-1539.

[2] D. W. Stephan and G. Erker, Angew. Chem. Int. Ed., 2010, 49, 4676.

[3] D. W. Stephan, S. Greenberg, T. W. Graham, P. Chase, J. J. Hastie S. J. Geier, J. M. Farrell, C. C. Brown, Z. M. Heiden, G. C. Welch and M. Ullrich, Inorg. Chem., 2011, 50, 12338-12348.

[4] T. Mahdi, Z.M. Heiden, S. Grimme, D.W. Stephan, J. Am. Chem. Soc. 2012, 134, 4088-4091.

[5] C. M. Mömming, E. Otten, G. Kehr, R. Fröhlich, S. Grimme, D. W. Stephan and G. Erker, Angew. Chem. Int. Ed., 2009, 48, 6643-6646.

[6] G. Ménard and D. W. Stephan, J. Am. Chem. Soc., 2010, 132, 17961797.

[7] L.J. Hounjet, C.B. Caputo, D.W. Stephan, Angew. Chem. Int. Ed 2012, 51, 4714-4717.

[8] G. Ménard and D. W. Stephan, Angew. Chem. Int. Ed. 2011, 51, 8396-8399.
Inorganic \& Coordination Chemistry, Lecture

All-Inorganic Design of Functional Nanomaterials Using Colloidal Nanocrystals

\section{Maksym V. Kovalenko (Prof. Dr.)}

ETH Zurich, Laboratory for Inorganic Chemistry, Department of Chemistry and Applied Biosciences, CH-8093, Zürich, Switzerland

EMPA - Swiss Federal Laboratories for Materials Science and Tehcnology, CH-8600, Dübendorf, Switzerland

Many materials in the form of well-defined nanoscale crystals ("nanocrystals") exhibit unique properties due to size effects and large surface-to-volume ratios. Yet it is clear that the utilization of nanomaterials in modern technologies requires their integration into solid-state structures with programmable electronic, magnetic and optical properties. The clear challenge is the rational design of this novel type of condensed matter, in which the size-tunable individual properties of nanoscale building blocks are enhanced by their interactions and by the macroscopic properties of their ensembles.

To achieve high degree of electronic coupling, the nanocrystal surface chemistry and surrounding medium need to be properly engineered. To address these issues, a new, general approach for replacing highly insulating organic capping ligands from the nanocrystal surface with electronically conductive inorganic molecular species has been developed [1]. The combinations of common metals and chalcogens (chalcogenidometalates) such as $\mathrm{SnS}_{4}{ }^{4-}, \mathrm{SnTe}_{4}{ }^{4-}, \mathrm{In}_{2} \mathrm{Se}_{4}{ }^{2-}, \mathrm{Sn}_{2} \mathrm{~S}_{6}{ }^{4-}, \mathrm{SbSe}_{4}{ }^{3-}$ etc. were employed as surface capping ligands. We will discuss various aspects of the synthesis, assembly, and integration of all-inorganic nanocrystals into field-effect transistors, infrared devices [2] and electrochemical storage media (Li-ion batteries).

[1] M. V. Kovalenko, M. Scheele, D. V. Talapin, Science, 324 (2009), 1417-1420.

[2] M. V. Kovalenko, R. D. Schaller, D. Jarzab, M. A. Loi, D. V. Talapin, Journal of the American Chemical Society, 134 (2012), 2457-2460
Dr. Max Lüthi Award 2012, Lecture

Effect of Mass Deacidification (Papersave Swiss Process) on Iron Gall Inks and Ink Corrosion

\section{Lucie Sägesser and Achim Ecker}

Zurich University of Applied Sciences, Institute of Chemistry and Biological Chemistry, Campus Reidbach, CH-8812 Wädenswil, Switzerland

Iron gall inks and their components induce degradation of cellulose due to acid hydrolysis and catalytic oxidative activity of iron ions. This process is called ink corrosion of paper and leads to the destruction of historical documents. The treatment of affected paper with a mass process - as already successfully applied for acid decay of paper - would be an economic alternative to the expensive manual treatment. The treatment of iron gall ink corroded model papers showed positive results in an empirical study [1]. In addition, studies of paper manufacture showed a inhibiting effect of magnesium ions on iron catalyzed oxidation processes [2].

Chemical trials were necessary to reproduce this positive effect in the laboratory and analyse the effect of the papersave swiss process on iron gall inks. To understand the complex system of iron gall inks in combination with dissolved magnesium and titanium alkoxides (METE, [3]) of the papersave swiss process, a combined preparative and analytical approach was pursued.

Thin-layer chromatography (TLC) on cellulose plates proved to be an appropriate model system to visualise the immobilisation of iron ions after the treatment with METE and pure magnesium alkoxides. The crystallisation of defined $\mathrm{Mg} / \mathrm{Fe}$ - compounds was so far not successful due to a gelation of the magnesium alkoxides in contact with humidity. Extraction of iron ions out of dried gels with buffered solutions showed a $\mathrm{pH}$ dependence of the immobilisation.

[1] Effner, C., Hochschule der Künste Bern, Diploma Thesis 2008

[2] Abbot, J.; Brown, D.G., Can. J. Chem. 1990, 68, 1537-1543.

[3] Yanovskaya, M.I. et al., J. Sol-Gel Sci. Technol. 1998, 11, 23-29. 
Inorganic \& Coordination Chemistry, Talk

An Anesthetic Agent for Kharasch Reactions

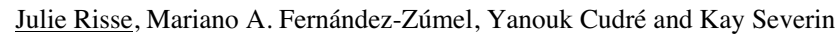

Institut des Sciences et Ingénieries Chimiques, École Polytechnique Fédérale de Lausanne (EPFL), 1015 Lausanne.

A two steps process for the synthesis of substituted trifluoromethyl cyclopropanes has been developed ${ }^{[1]}$ Halothane, an anesthetic agent, is added to olefins in an atom transfer radical process in the presence of the catalys $\mathrm{Cp} * \mathrm{RuCl}_{2}\left(\mathrm{PPh}_{3}\right)\left(\mathrm{Cp}^{*}=\right.$ pentamethylcyclopentadienyl $)$ and $\mathrm{Mg}$. The latter allows a second dehalogenation step initiated by THF. Trifluoromethyl substituted cyclopropanes were obtained in good yields from different olefins. Our procedure represents a mild alternative to the widely used method involving the use of toxic diazo compounds.

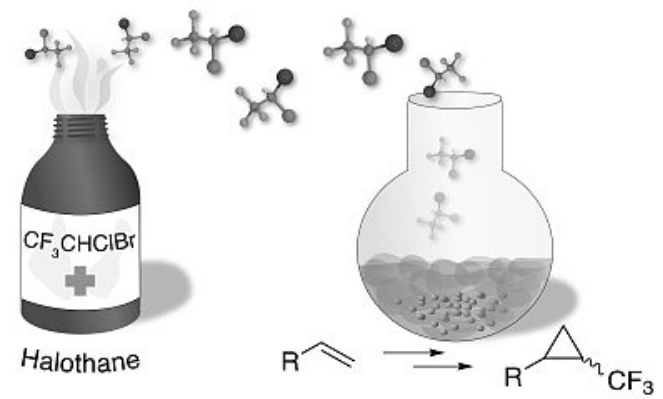

[1] Julie Risse, Mariano A. Fernández-Zúmel, Yanouk Cudré and Kay Severin, submitted.

Inorganic \& Coordination Chemistry, Talk

Polypyridyl Complexes as Potential New Photosensitizers and/or Water Reducing Catalysts

Cyril Bachmann, Roger Alberto*

Institute of Inorganic Chemistry, University of Zürich, Winterthurerstr. 190, CH-8057 Zürich, Switzerland

Our current studies indicate that the polypyridyl complex [Co(TPy) $\left.\mathrm{Br}_{2}\right](\mathbf{1})$ has outstanding properties as water reducing catalyst (WRC) in photocatalyzed aqueous hydrogen production. ${ }^{1}$ In order to get a better mechanistic understanding and to find even more efficient water reducing catalysts and/or cheaper photosensitizers, several further polypyridyl ligands and their $\mathrm{Mn}, \mathrm{Co}, \mathrm{Fe}, \mathrm{Ni}, \mathrm{Cu}, \mathrm{Zn}$ and $\mathrm{Ru}$ complexes were synthesized.

The corresponding complexes were fully characterized and the photophysical and photochemical properties investigated. So far, $[\mathrm{Co}(2) \mathrm{Br}] \mathrm{Br}$ and $[\mathrm{Co}(\mathbf{3}) \mathrm{Br}] \mathrm{Br}$ showed comparable or even better activities than WRC $\mathbf{1}$.
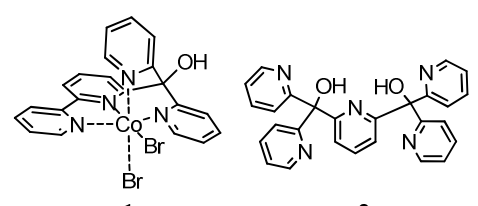

2

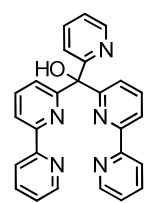

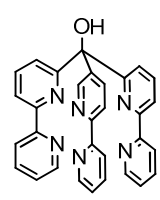

4
Scheme 2: WRC1 and other synthesized polypyridyl ligands.

[1] B. Probst., M. Guttentag, A. Rodenberg, P. Hamm, R. Alberto, Inorg. Chem., 2011, 50, 3404-3412
Inorganic \& Coordination Chemistry, Talk

Chiroptical Properties of Intrinsically Chiral Thiolate-Protected Gold Clusters: Enantioseparation and Racemization Barriers of $\mathrm{Au}_{38}(\mathrm{SR})_{24}$ and $\mathrm{Au}_{40}(\mathrm{SR})_{24}$ clusters

$\underline{\text { Stefan Knoppe }}^{1}$, Igor Dolamic ${ }^{1}$, Thomas Bürgi ${ }^{1}$

${ }^{1}$ Department of Physical Chemistry, University of Geneva, 30 Quai ErnestAnsermet, 1211 Geneva 4

The field of thiolate-protected gold clusters of defined size has evolved as a vastly studied area in chemistry. Chiroptical responses of metal-based electronic transitions have been studied for more than a decade and chirality was found to be an inherent feature of certain cluster sizes, even if being protected by achiral ligands.[1]

We synthesized and size-selected $\mathrm{Au}_{38}(\mathrm{SR})_{24}$ and $\mathrm{Au}_{40}(\mathrm{SR})_{24}$ from heavier clusters. The intrinsic chirality of $\mathrm{Au}_{38}$ is known since its crystal structure was successfully solved, but no enantioseparation (or enantioselective synthesis) has been reported. We achieved enantioseparation of $\mathrm{Au}_{38}$ and $\mathrm{Au}_{40}$ with chiral HPLC and recorded its Circular Dichroism spectrum.[2a, 2b] These are the first CD spectra of gold clusters being protected by achiral ligands only. Furthermore, we performed racemization studies, which allow the determination of thermochemical parameters (activation barriers etc...) of structural rearrangements on cluster surfaces for the first time. We also propose a mechanistic model for the rearrangement.[2c] The method serves as a facile test for chirality in clusters of unknown sizes and aids in answering the question whether or not chirality is an ubiquitous feature of thiolateprotected gold clusters.

[1] a) Gautier, Bürgi, ChemPhysChem 2009, 10, 483; b) Jadzinsky, Calero, Ackerson, Bushnell, Kornberg, Science 2007, 318, 430. [2] a) Dolamic, Knoppe, Dass, Bürgi, Nat. Commun. 2012, accepted; Knoppe, Dolamic, Dass, Bürgi, submitted c) Knoppe, Dolamic, Bürgi, in preparation.

Inorganic \& Coordination Chemistry, Talk

Water Soluble $\left[\mathrm{Fe}_{4} \mathrm{~L}_{6}\right]^{8+}$ Cages and Their Host Guest Chemistry Jeanne L. Bolliger ${ }^{1}$, Jonathan R. Nitschke*1

${ }^{1}$ University of Cambridge, Department of Chemistry, Lensfield Road, Cambridge, CB2 1EW, United Kingdom

Building upon the success of the smaller $\left[\mathrm{Fe}_{4} \mathrm{~L}_{6}\right]$ cage, ${ }^{[1]}$ several larger functionalised, water soluble tetrahedral cages have been synthesised via subcomponent self-assembly. In order to maintain the tetrahedral structure of the cage molecules, the subcomponents of these cages are linear dianilines and consist of terphenylene (as shown in Scheme 1), pentaphenylene, and/or acetylene units.

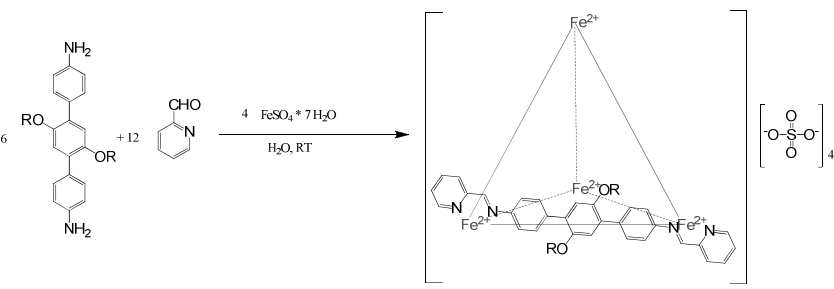

These large cage molecules were found to be water soluble. Binding of various interesting guests into the hydrophobic cavity of the $\left[\mathrm{Fe}_{4} \mathrm{~L}_{6}\right]^{8+}$ cages was observed by NMR.

[1] (a) P. Mal, D. Schultz, K. Beyeh, K. Rissanen, J.R. Nitschke, Angew. Chem., Int. Ed. 2008, 47, 8297; (b) P. Mal, B. Breiner, K. Rissanen, J.R. Nitschke, Science 2009, 324, 1697; (c) I. A. Riddell, M. M. J. Smulders, J. K. Clegg and J. R. Nitschke, Commun., 2011, 47, 457. 
Inorganic \& Coordination Chemistry, Talk

Unexpected cycloaddition of $\mathrm{NaOCP}$

Xiaodan Chen, Hansjörg Grützmacher

Department of Chemistry and Applied Biology, ETH Zurich CH-8093

We had recently reported a simple synthesis of $\mathrm{NaOCP}$ [1] which contains a $\mathrm{C} \equiv \mathrm{P}$ triple bond. We set out to investigate the cycloaddition chemistry of this new organophosphorus building block and detected that this is full of surprises. While the formation of a phosphophenolate was expected in the reaction of $\mathrm{NaOCP}$ with tetracyclone under extrusion of $\mathrm{CO}$, new phosphorus heterocycles were isolated instead. One is the isophosphindole-1, 3-dione (1); the other (2) contains a five membered ring with two phosphorus atoms linked through a $\mathrm{P}=\mathrm{P}$ bond. This type of heterocycle has never been reported before; the P-P bond length is in between a typical single bond ( $2.23 \AA$ ) and a double bond $(2.03 \AA)$ and indicates a delocalized pi-system [2] Compound 1 contains likewise a delocalized O-C-P-C-O pi-system the formation of which is seemingly the driving force for the unexpected formation of 1 .

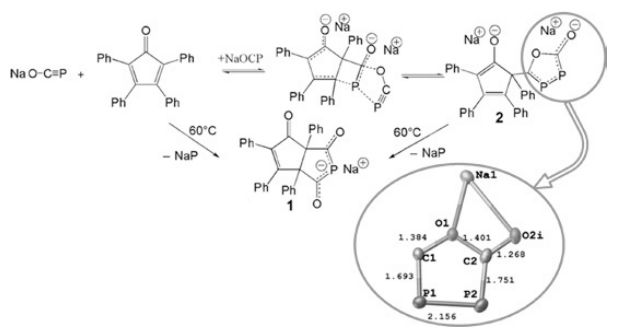

Figure 1 The schematic view of cycloaddition of $\mathrm{NaOCP}$ and tetracyclone and parts of the crystal structures of 2 ( i:-x, 1-y, -z) with bond lengths $(\AA)$.

[1] F. F. Puschmann, D. Stein, et. al., Angew Chem Int Edit 2011, 50, 8420.

[2] J. Emsley, D. Hall, Harper and Row, London, 1976, p. 34.

Inorganic \& Coordination Chemistry, Talk

Single-molecule studies of RNA - metal ion interaction

Sebastian L.B. König, Danny Kowerko, Mokrane Khier, Roland K.O. Sigel

University of Zurich, Winterthurerstrasse 190, CH-8057, Switzerland

Group II introns are catalytic elements found within RNA of numerous organisms and they are involved in RNA maturation through catalysis of their own excision. Single-molecule Förster Resonance Energy Transfer (smFRET) experiments using derivatives of the group II intron Sc.ai5 $\gamma$ allowed us to reveal a new, cation-dependent folding paradigm $[1,2]$.
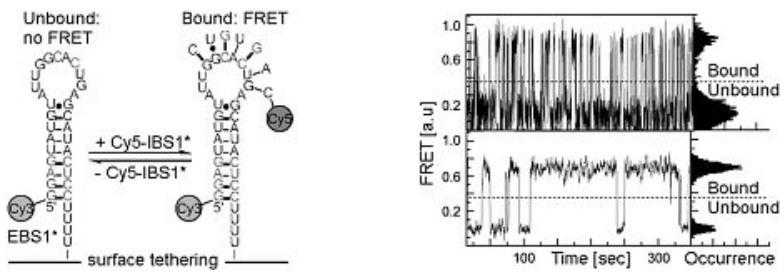

We study the influence of various divalent metal ions on 5' splice site recognition by smFRET using a system of short exon/intron recognition sequences (EBS1/IBS1). Divalent metal ions were shown to be crucial for interaction, though, to a different extent strongly dependent on the metal ion present. Kinetic subspecies were identified, characterised, and the results correlated to bulk measurements. The present study validates smFRET for the systematic study of metal ion/nucleic acid interaction and suggests a general approach to describe heterogeneities often observed in single-molecule experiments.

Financial support: European Research Council and the University of Zurich.

[1] M. Steiner, K.S. Karunatilaka, R.K.O. Sigel, D. Rueda, Proc. Natl. Acad. Sci. USA 2008, 105, 13853.

[2] M. Steiner, D. Rueda, R.K.O. Sigel, Angew. Chem. Int. Ed. Engl. 2009 $48,9739$.
Inorganic \& Coordination Chemistry, Talk

First Method for Rapid Blood Cyanide Detection with a Metal-Based Chemosensor

\section{Christine Männel-Croisé, Felix H. Zelder}

Institute of Inorganic Chemistry, University of Zurich, Winterthurer Str.190, 8057 Zurich

Smoke toxicity from fires is increasingly caused by hydrogen cyanide, generated by the combustion of synthetic polymers. The treatment of firevictims with cyanide antidotes directly at the scene is still based on presumptive diagnostics because a straightforward detection method is not yet available. $^{[1]}$

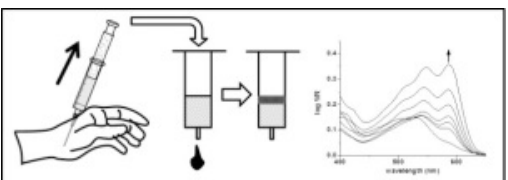

We present the first method for rapid cyanide detection in blood using a hydrophobic metal-based chemosensor and colorimetric solid-phase extraction. ${ }^{[2]}$ Qualitative and quantitative determinations are possible. Applications in emergency situations are envisaged.

[1] A. E. Lindsay, A. R. Greenbaum and D. O'Hare, Anal. Chim. Acta, 2004, 511, 185-195.

[2] C. Männel-Croise and F. Zelder, submitted, 2012.
Inorganic \& Coordination Chemistry, Talk

Investigations on the metal-sulfide-thiolate cluster of metallothioneins

\section{Tamara Huber, Eva Freisinger}

Institute of Inorganic Chemistry, University of Zürich, Winterthurerstr. 190 8057 Zürich, Switzerland

Metallothioneins (MTs) are a large family of ubiquitous, small, and cysteine rich proteins with the ability to bind metal ions. Previous investigations on the plant MT2 from Cicer arietinum (chickpea; cicMT2) showed increased metal incorporation into the metal-thiolate cluster in presence of additional sulfide ligands [1]. The presence of sulfide ions in plant and other MTs has already been reported previously [2], but the mechanism of the incorporation remains still unclear and is investigated more closely.

The dimension of the metal-sulfide-thiolate cluster is depending on the initial available free sulfide concentration. In the case of the cicMT2, the cluster can be enlarged to a multiple size of the one without sulfide ions. The most important factor for the sulfide ion incorporation is the chronology of the addition of the educts. Only in a specific order of addition it is possible to achieve a metalsulfide-thiolate cluster in the cicMT (Fig.). A comperative analysis with the well studied rabbit MT2A [3] verifies these findings.

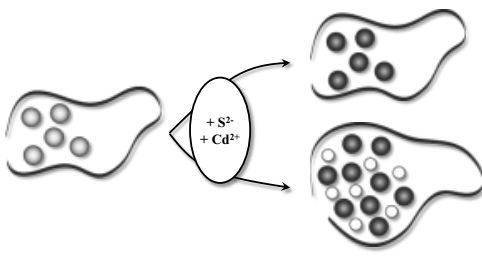

Fig. Incorporation of sulfide ions and hence enlargement of the cluster size depends on the sequence of sulfide and metal ion addition.

Financial support from the Swiss National Science Foundation is gratefully acknowledged (SNSF-Professorship PP002-119106/1 to EF).

[1] X. Wan, PhD Thesis, University of Zurich 2009.

[2] M. Capdevila, J. Domènech, A. Pagani, L. Tío, L. Villarreal, S. Atrian, Angew. Chem. Int. Ed. 2005, 44, 4618.

[3] M. Good, R. Hollenstein, M. Vašák, Eur. J. Biochem. 1991, 197, 655. 
Inorganic \& Coordination Chemistry, Talk

Engineering Novel Gold(III) Luminophores

Jai Anand Garg, Alexander Szentkuti, Olivier Blacque, Koushik Venkate-

$$
\underline{\mathrm{san}^{*}}
$$

Institute of Inorganic Chemistry, University of Zürich, Winterthurerstrasse

$$
\text { 190, CH-8057, Zürich, Switzerland }
$$

Owing to their interesting luminescent properties, Ir(III) and Pt(II) have been intensively investigated during the last decade for applications in Phosphorescent OLEDs (PhOLEDs) ${ }^{[1]}$ In quite contrast to the extensive investigation on $\mathrm{Pt}(\mathrm{II})$ complexes,${ }^{[2]}$ the luminescence properties of isoelectronic $\mathrm{Au}(\mathrm{III})$ complexes are less explored. ${ }^{[3]}$ We have recently developed novel classes of mono-cyclometalated $\mathrm{Au}$ (III) molecules bearing different ancillary ligands that gave rise to complexes with exceptional thermal stability and phosphorescence properties ${ }^{[4]}$ The judicious choice of the cyclometalate allows a facile way to tune the emission properties. The excited state lifetimes coupled with their luminescent properties in the solid-state could make these complexes compatible for applications in PhOLEDs as the next generation triplet phosphors.

[1] Yersin, H.; Finkenzeller, W. J.; in Highly Efficient OLEDs with Phosphorescent Materials, (Ed: H. Yersin), Wiley-VCH, Weinheim, 2007.

[2] Chassot, L.; Müller, E.; von Zelewsky, A. Inorg. Chem. 1984, 23, 4249.

[3] Wong, K. M. -C.; Hung, L. -L.; Lam, W. H.; Zhu, N.; Yam, V. W. -W. J. Am. Chem. Soc. 2007, 129, 4350.

[4] (a) Garg, J. A.; Blacque, O.; Fox, T.; Venkatesan, K. Inorg. Chem. 2010, 49, 11463. (b) Garg, J. A.; Blacque, O.; Venkatesan, K. Inorg. Chem. 2011, 5430. (c) Szentkuti, A.; Garg, J. A.; Venkatesan, K. 2012, Manuscript in preparation.
Inorganic \& Coordination Chemistry, Talk

\section{Valbond Force Field for Pianostool Complexes}

Maurus Schmid $^{1,2}$, Thomas R. Ward ${ }^{1, *}$, Markus Meuwly ${ }^{2, *}$

${ }^{1}$ University of Basel, Spitalstrasse 51, 4056 Basel

${ }^{2}$ University of Basel, Klingelbergstrasse 80, 4056 Basel

Pianostool type complexes play an important role in coordination chemistry. Complexes of this type can catalyze many reactions, especially for hydrogenation they are central.[1] The standard approach to compute these complexes relies on $a b$ initio methods like DFT. These $a b$ initio methods are slow and scale quite badly with the size of the system. If one wants to calculate a large number of structures for screening purposes or is interested in a large complex with many atoms, the computer power required becomes prohibitive and exceeds typically available resources. As transition metals in connection with proteins gain larger interest, the need for a fast and reliable computational method grows even more. The QM/MM approach can be a solution, but for some applications this is still not fast enough and full force fields are required. But still very few force fields are available that can cope with transition metals. Even fewer are able to cope with $\eta^{5}$ or $\eta^{6}$ type ligands. Valbond-Trans[2] is force field, that replaces the normal CHARMM[3] angle energy terms with terms based on the valence bond theory. It needs less parameters and can reproduce complicated geometries like $\mathrm{W}\left(\mathrm{CH}_{3}\right)_{6}$. [4] We set out to parameterize the CHARMM and Valbond-Trans force fields to cope with ligands of the $\eta^{5}$ or $\eta^{6}$ type.

[1] Wang, C.; Villa-Marcos, B.; Xiao, J., ChemComm 2011, 47, 9773.

[2] Tubert-Brohman, I.; Schmid, M.; Meuwly, M. JCTC 2009, 5, 530.

[3] Brooks, B. R.; Bruccoleri, R. E.; Olafson, D. J.; States, D. J.; Swaminathan, S.; Karplus, M. J. Comput. Chem., 1983, 4, 187.

[4] Landis, C. R.; Cleveland, T.; Firman, T. K. J. Am. Chem. Soc. 1995 117, 1859.
Inorganic \& Coordination Chemistry

Hydrogenation of Quinoline by Hectorite-Supported Ruthenium Nanoparticle:

\section{Bing Sun, Farooq-Ahmad Khan, Georg Süss-Fink*}

Université de Neuchâtel, CH-2000 Neuchâtel, Switzerland

Reduction of $N$-heteroaromatic compounds such as quinoline is of great importance, since valuable intermediates thus obtained are widely used as building blocks for specialty fine chemicals [1] and for petrochemicals [2].

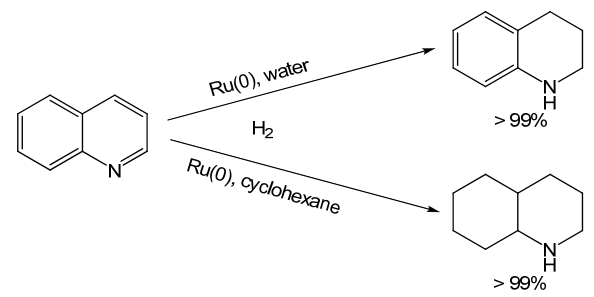

We report ruthenium nanoparticles intercalated in hectorite to be a highly efficient (conversion $100 \%$ ) and highly selective (selectivity $>99 \%$ ) catalyst for the hydrogenation of quinoline $(\mathrm{Q})$ to give either 1,2,3,4-tetrahydroquinoline (THQ) or decahydroquinoline (DHQ) under mild conditions $\left(80-100^{\circ} \mathrm{C}\right.$, $30-50$ bar $\mathrm{H}_{2}$ ) in water and cyclohexane, respectively.

[1] A. R. Kartritzky, S. Rachwal, B. Rachwal, Tetrahedron 52 (1996) 15031. [2] G. Perot, Catal. Today 10 (1991) 447.
Inorganic \& Coordination Chemistry

Coordination Isomers of Arene Ruthenium Complexes containing Chelating 2,2'-Dipyridyl- $N$-arylimine Ligands

Mathiyazhagan Ulaganatha Raja, Bruno Therrien, Georg Süss-Fink*

Institute of Chemistry, University of Neuchatel, Neuchatel, Switzerland. E-mail: georg.suess-fink@unine.ch

Ruthenium complexes are extremely versatile molecules. In particular, cationic arene ruthenium complexes, which are air-stable and watersoluble, find increasing interest as homogeneous catalysts, nanocages and nanoparticle precursors. Notably, arene ruthenium compounds are also being explored for their biological properties as anticancer agents [1-3].

Herein, we report a series of water-soluble cationic arene ruthenium(II) complexes of the general formula $\left[\mathrm{Ru}\left(\eta^{6}-p \text {-cymene }\right)\left(\eta^{2}-\mathrm{L}\right) \mathrm{Cl}\right]^{+}[\mathrm{L}=$ $2,2^{\prime}$-dipyridyl- $N$-arylimine ligands] that have been synthesized from the reaction of $\left[\mathrm{Ru}\left(\eta^{6}-p \text {-cymene }\right) \mathrm{Cl}_{2}\right]_{2}$ with several $2,2^{\prime}$-dipyridyl- $N$-arylamines in methanol in 1:2 molar ratio. Two isomers have been isolated from this reaction as the tetrafluoroborate salts and characterized in two cases by singlecrystal X-ray structure analysis. The catalytic activity of the synthesized complexes will be discussed.
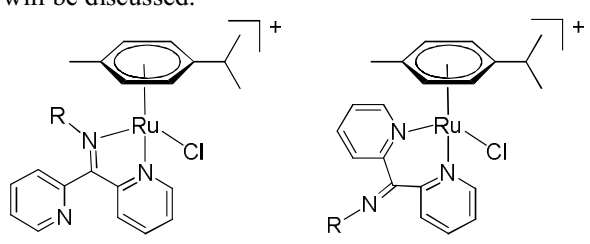

$\mathrm{R}=$ 2,4,6-trimethylphenyl or 2,6-diisopropylphenyl

[1] J. Canivet, G. Süss-Fink, Green Chem., 2007, 9, 391.

[2] B. Therrien, G. Süss-Fink, Coord. Chem. Rev., 2009, 253, 2639.

[3] M. Ulaganatha Raja, R. Ramesh, J. Organomet. Chem., 2012, 699, 5. 
Inorganic \& Coordination Chemistry

Highly cytotoxic trithiolato diruthenium complexes of the type $\left[\left(\eta^{6}-p-\right.\right.$ $\left.\left.\mathrm{MeC}_{6} \mathrm{H}_{4} \mathrm{Pr}^{\mathrm{i}}\right)_{2} \mathrm{Ru}_{2}(\mathrm{SPh}-\mathrm{R})_{3}\right]^{+}$: correlation between cytotoxicity, Hammett constants and lipophilicity

Federico Giannini $^{1}$, Julien Furrer ${ }^{1}$, Georg Süss-Fink ${ }^{2}$

${ }^{1}$ Department of Chemistry and Biochemistry, University of Berne, Freiestrasse 3, 3012 Berne

${ }^{2}$ Institut de Chimie, University of Neuchâtel, Avenue de Bellevaux 51, 2000 Neuchâtel

Ruthenium complexes possess interesting anticancer activity and few side effects compared to platinum complexes and may be strong candidates for rational drug design. [1], [2] However, for most of these systems, the mode of action, uptake and biological processes are still poorly understood.

We have synthesized first a family of highly cytotoxic trithiolato-bridged dinuclear arene Ru-complexes, with $\mathrm{IC}_{50}$ values against $\mathrm{A} 2780$ and A2780cisR cellular lines being in the submicromolar range, [3] of the general formula $\left[(\mathrm{p} \text {-cymene })_{2} \mathrm{Ru}_{2}(\mathrm{SPh}-\mathrm{p}-\mathrm{R})_{3}\right]^{+}$and analysed their interaction with amino acids, nucleotides and glutathione under physiological conditions.

Surprisingly, these compounds remained inert against nucleotides and amino acids, and we discovered that they can actually act as efficient catalyst for the oxidation of the cysteinyl group of GSH to the glutathione disulphide form (GSSG). [4]

Preliminary results obtained with $o^{-}, m_{-}$, and $d i$ - substituted thiol groups as ligands, and in particular tentative correlations between Hammett's constants $\left(\sigma_{\mathrm{p}}\right), \mathrm{IC}_{50}$ and lipophilicity $(\log \mathrm{P})$, will be also presented provide a first insight into the possible mode of action of these Ru-complexes. [5]

[1] G. Süss-Fink, Dalton Trans. 2010, 39, 1673

[2] G. Gasser, I. Ott, N. Metzler-Nolte, J. Med. Chem. 2011, 54, 3.

[3] M. Gras et al., Dalton Trans. 2010, 39, 10305-10313.

[4] F. Giannini, G. Süss-Fink, J. Furrer, J. Inorg. Chem. 2011, 50, 10552.

[5] L. Fetzer et al, Dalton Trans. 2011, 40, 8869.

Inorganic \& Coordination Chemistry

Synthesis, Characterization and Anticancer Activity of ThiolatoBridged Arene Ruthenium Metalla-Prisms

Amine Garci, Mona A. Furrer, Bruno Therrien*

University of Neuchatel, Institute of Chemistry, Avenue de Bellevaux 51, CH-2000 Neuchatel, Switzerland

Three hexacationic metalla-prisms have been synthesized following a onepot strategy. Neutral dithiolato-diruthenium complexes ${ }^{[1]}$ react in ethanol at room temperature in the presence of silver trifluoromethanesulfonate (halide scavenger) and 2,4,6-tri(pyridin-4-yl)-1,3,5-triazine (donor ligand) to give the metalla-hexanuclear cations $(\mathbf{1}-\mathbf{3})$ isolated as trifluoromethanesulfonate salts in good yield $(\approx 80 \%)$. All compounds are found to be highly cytotoxic toward the human ovarian cancer cell lines A2780 and A2780cisR, thus providing a new family of highly cytotoxic multinuclear arene ruthenium complexes. $^{[2]}$

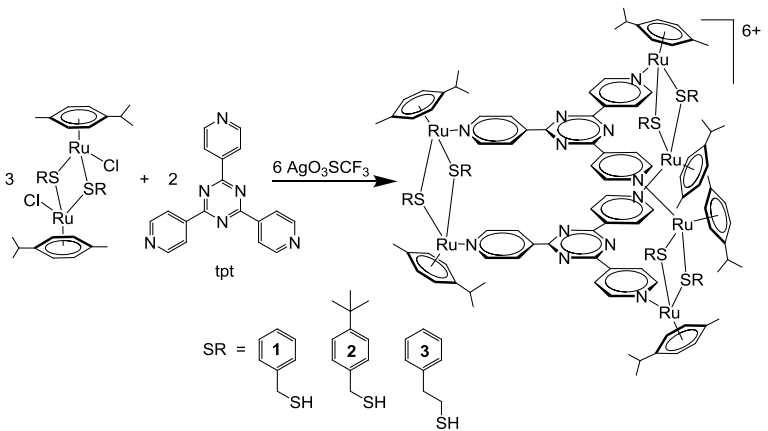

[1] A.-F. Ibao, M. Gras, B. Therrien, G. Süss-Fink, O. Zava, P. J. Dyson, Eur. J. Inorg. Chem., 2012, 1531.

[2] G. S. Smith, B. Therrien, Dalton Trans., 2011, 40, 10793.
Inorganic \& Coordination Chemistry

Comparative study of the behavior of different ruthenium-hexacationic cages towards biological ligands utilizing NMR spectroscopy

Lydia Paul $^{1}$, Julien Furrer ${ }^{1}$, Bruno Therrien ${ }^{2}$

\footnotetext{
${ }^{1}$ Departement of Chemistry and Biochemistry, University of Berne, Freiestrasse 3, 3012 Berne.

2 Institut de Chimie, University of Neuchatel, rue Emile Argand 11,
} 2009, Neuchâtel.

Ruthenium-based anticancer drugs received much attention over the last decades since they are known to possess less severe side effects than the well-used platinum drugs. [1]-[3]

Recently, we and other groups designed different ruthenium metalla assemblies, especially hexacationic metallaprisms, which can encapsulate various planar molecules either permanently or reversibly. This property makes the metalla cages useful in drug delivery since the can act as "Trojan Horses" to deliver drugs into cancer cells. [4], [5]

The aim of our work was to determine the behaviour of different metalla cages under physiological conditions with or without a guest molecule encapsulated using various NMR techniques and thereby find possible biological targets of these molecules in biological media. To find these targets the interactions of the metalla assemblies with amino acids, nucleotides, glutathione, and other selected biomolecules like glucose, lactic acid or ascorbic acid were monitored.

[1] M. J. Clarke, Met. Ions Biol. Syst. 1980, 11, 231.

[2] B. Rosenberg et al., J. Biol. Chem. 1967, 242, 1347.

[3] G. Suess-Fink, Dalton Trans. 2010, 39, 1673.

[4] M. Wang et al., Inorg Chem. 2011, 50, 1506.

[5] B. Therrien et al., Angew. Chem. Int. Ed. 2008, 47, 3773.

Inorganic \& Coordination Chemistry

230

Hydrosoluble pyrenyl-dendrimers and arene ruthenium metalla-cages: synergic enhancement of cytotoxicity

Anaïs Pitto-Barry ${ }^{1}$, Nicolas P. E. Barry ${ }^{1}$, Olivier Zava ${ }^{2}$, Paul J. Dyson ${ }^{2}$, Robert Deschenaux ${ }^{1}$ and Bruno Therrien* ${ }^{1}$

${ }^{1}$ Institut de Chimie, Université de Neuchâtel, Avenue de Bellevaux 51, CH-2000 Neuchâtel, Switzerland

${ }^{2}$ Institut des Sciences et Ingénierie Chimique, Ecole Polytechnique Fédérale de Lausanne (EPFL), CH-1015 Lausanne, Switzerland

Pyrenyl bis-MPA dendrimers with different end-groups were synthesized and the pyrenyl part encapsulated in two arene ruthenium metalla-cages, $\left[\mathrm{Ru}_{6}(p \text {-cymene })_{6}(O O \cap O O)_{3}(\mathrm{tpt})_{2}\right]^{6+}(O O \cap O O=$ 5,8-dioxydo-1,4-naphtaquinonato and 6,11-dioxydo-5,12-naphtacenedionato; $\mathrm{tpt}=2,4,6$-tri(pyridin4 -yl)-1,3,5-triazine). The host-guest properties of the [guest $\subset$ cage] ${ }^{6+}$ systems were studied by spectroscopic methods, thus allowing the determination of their affinity constants. Moreover, the cytotoxicity of the watersoluble host-guest systems and the pyrenyl-dendrimers was evaluated on human ovarian cancer cells [1] and compared to analogous systems [2].
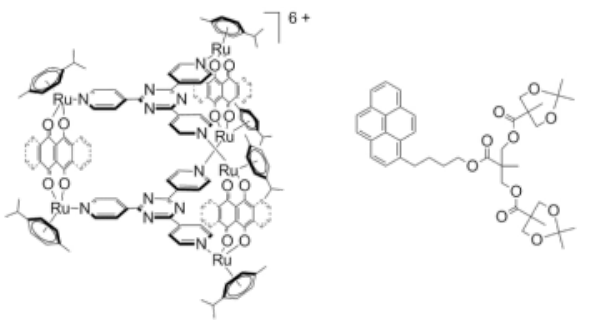

[1] A. Pitto-Barry, O. Zava, P. J. Dyson, R. Deschenaux, B. Therrien, submitted.

[2] A. Pitto-Barry, N. P. E. Barry, O. Zava, P. J. Dyson, R. Deschenaux, B. Therrien, Chem. Eur. J. 2011, 17, 1966. 
Inorganic \& Coordination Chemistry

Porphyrin Containing Sawhorse-Type Diruthenium Tetracarbonyl Complexes and their Applications

Justin P. Johnpeter, Bruno Therrien*

Institut de Chimie, Université de Neuchâtel, Ave de Bellevaux 51, CH-2000 Neuchâtel, Suisse

Among photodynamic therapy agents, porphyrin derivatives remain one of the most studied. This is due to their efficiency in producing singlet oxygen in presence of light which subsequently kill the cancer cells. Porphyrins are electron rich due to their aromaticity and are useful for studying molecular recognition. Moreover sawhorse-type diruthenium tetracarbonyl complexes have numerous applications in the field of biological and supramolecular chemistry ${ }^{[1]}$ In this poster, we will discuss the anticancer properties of sawhorse-type diruthenium tetracarbonyl complexes containing porphyrinic units, ${ }^{[2]}$ as well as their ability to act as molecular tweezers. ${ }^{[3]}$

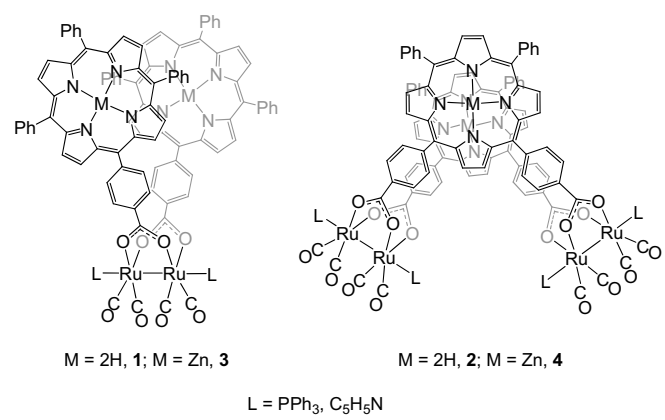

[1] B. Therrien, G. Süss-Fink, Coord. Chem. Rev., 2009, 253, 2639.

[2] J. P. Johnpeter, F. Schmitt, L. Juillerat-Jeanneret, B. Therrien, submitted.

[3] J. P. Johnpeter, J. Mohanraj, N. Armaroli, B. Therrien, submitted.
Inorganic \& Coordination Chemistry

Activation of Nitrous Oxide by N-Heterocyclic Carbenes

$$
\underline{\text { Alexander Tskhovrebov }}^{1} \text { and Kay Severin }{ }^{1}
$$

${ }^{1}$ Ecole Polytechnique Fédérale de Lausanne (EPFL), CH-1015 Lausanne, Switzerland

Nitrous oxide $\left(\mathrm{N}_{2} \mathrm{O}\right)$ is a problematic compound from an environmental point of view because it is a very efficient greenhouse gas and an ozonedepleting substance. From a synthetic point of view, $\mathrm{N}_{2} \mathrm{O}$ is interesting because it has a high oxidation potential. However, chemical transformations of $\mathrm{N}_{2} \mathrm{O}$ are hampered by is its inert character.

Recently we discovered that N-heterocyclic carbenes are able to fix $\mathrm{N}_{2} \mathrm{O}$ and form stable adducts. ${ }^{1}$ These adducts could be regarded as a source of activated $\mathrm{N}_{2} \mathrm{O}$ and they display unique reactivity as evidenced by different organic and organometallic transformations. ${ }^{1,2}$

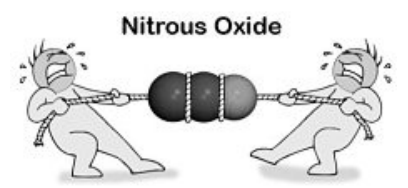

[1] A. G. Tskhovrebov, E. Solari, M. D. Wodrich, R. Scopelliti, K. Severin, Angew. Chem. Int. Ed. 2012, 51(1), 232-234.

[2] A. G. Tskhovrebov, E. Solari, M. D. Wodrich, R. Scopelliti, K. Severin, J. Am. Chem. Soc. 2012, 134(3), 1471-1473.
Inorganic \& Coordination Chemistry

Functionalised Clathrochelates as Building Blocks in Structural Supramolecular Chemistry

Matthew Wise, Kay Severin

Institut des Sciences et Ingénierie Chimiques, Ecole Polytechnique Fédérale de Lausanne, 1015 Lausanne, Switzerland

Self-assembly has been proven to be a powerful technique in the synthesis of supramolecular architectures, the structure and function of which depend critically upon the nature of their component building blocks.[1] Hence the ability to tune and exploit the structural and chemical properties of these building blocks is essential to the targeted design of self-assembled systems with novel characteristics. We have begun to investigate a new family of supramolecular building blocks, based upon boronic acid capped, functionalized iron(II) tris-dioximate clathrochelate complexes. These tectons exhibit several desirable characteristics for self-assembly applications including rigidity, extensive scope for structural and functional modification, and straightforward synthesis. Furthermore, the potential of these systems as building blocks is demonstrated through the preparation of discrete macrocycles and a heterometallic coordination polymer.
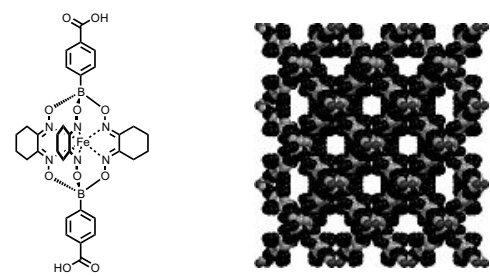

[1] R. Chakrabarty, P.S. Mukherjee, P.J. Stang, Chem. Rev. 2011, 111, 6810
Inorganic \& Coordination Chemistry

Structural and Catalytic Investigations on $\mathrm{Co}(\mathrm{II})$ and $\mathrm{Co}(\mathrm{I})$ Complexes with the Bis(diphenylphosphino)ethane Ligand

Gregor Kiefer, Heron Vrubel, Rosario Scopelliti and Kay Severin

Institut des Sciences et Ingénierie Chimiques, Ecole Polytechnique Fédérale de Lausanne (EPFL), CH-1015 Lausanne, Suisse

The composition of the widely used pre-catalysts $\left[\mathrm{CoX}_{2} \mathrm{dppe}\right](\mathrm{X}=\mathrm{Cl}$, $\mathrm{Br}, \mathrm{I})$ for $\mathrm{C}-\mathrm{C}$ coupling reactions is different than assumed so far. X-ray diffraction experiments showed that they are complex salts with the formula $\left[\left(\mathrm{CoXdppe}_{2}\right)_{2}\left(\mathrm{Co}_{2} \mathrm{X}_{6} \mathrm{dppe}\right)\right]$. Electronic spectroscopy experiments showed that they keep their structure in solution. Moreover, the cations and anions of $\left[\left(\mathrm{CoXdppe}_{2}\right)_{2}\left(\mathrm{Co}_{2} \mathrm{X}_{6} \mathrm{dppe}\right)\right]$ have been independently crystallized with tetrabutylammonium or tetraphenylborate as counter ions.

In many $\mathrm{C}-\mathrm{C}$ coupling reactions catalyzed by "[CoX $\left.\mathrm{Cop}_{2} \mathrm{dppe}\right]$ " in combination with a reducing agent (f. ex. $\mathrm{Zn}$ or $\mathrm{NaBH}_{4}$ ), a $\mathrm{Co}(\mathrm{I})$ species is believed to be the active species. However, no experimental proof for this has been given so far. The new $\mathrm{Co}(\mathrm{I})$ complexes $\left[\mathrm{CoX}(\mathrm{dppe})\left(\mathrm{PPh}_{3}\right)\right]$ and $\left[\mathrm{CoI}(\mathrm{dppe})\left(\eta^{4}-\right.\right.$ isoprene)] were shown to be highly efficient catalysts for the Diels-Alder reaction of unactivated substrates, the branched 1,4-hydrovinylation and the chemoselective $[2+2+2]$ cycloaddition of two different alkynes. The use of the defined $\mathrm{Co}(\mathrm{I})$ complexes resulted in shorter reaction times and permitted in some cases lower catalyst loadings than by using $\mathrm{Co}$ (II) precursors that are reduced in situ. 
Inorganic \& Coordination Chemistry

$\mathrm{Ru}$-based cages as receptors for alkali metal ions

\section{Clément Schouwey, Rosario Scopelliti and Kay Severin}

Ecole Polytechnique Fédérale de Lausanne, 1015 Lausanne, Switzerland

Metallacrown complexes are metal-based macrocycles analogous to crown ethers. Our group has shown that $\mathrm{Ru}$ metallacrowns can bind $\mathrm{Li}^{+}$ions strongly and selectively in water. ${ }^{[1]}$ Recently, we demonstrated that modification of these metallacrown complexes to include aldehyde functionality allowed their reaction with various amines to form large, higher order structures. ${ }^{[2]}$ We have now synthesized the new complex $\mathbf{1}$ bearing amine functionalities. The trimer 1 reacts with the complementary aldehyde $\mathbf{2}$ to form the closed cage $\mathbf{3}$. The cage turned out to be a tritopic receptor for alkali metal ions. The two metallacrown subunits are able to bind the smaller ions $\mathrm{Li}^{+}$and $\mathrm{Na}^{+}$ions on the outside, whereas the larger cations $\mathrm{Rb}^{+}$and $\mathrm{Cs}^{+}$are bound inside the cage.

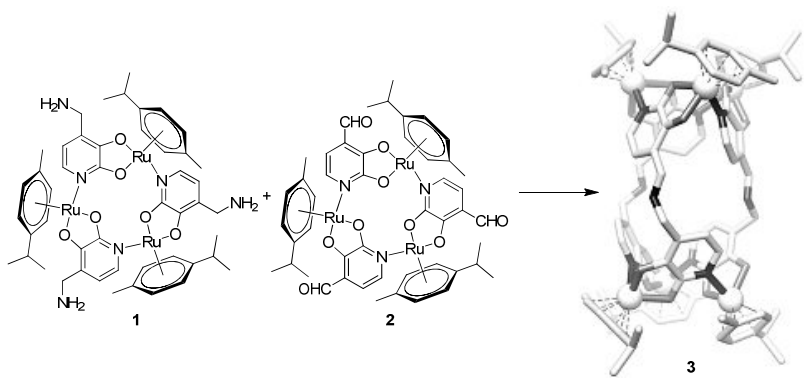

[1] Z. Grote, M.-L. Lehaire, R. Scopelliti and K. Severin, J. Am. Chem. Soc. 2003, 125, 13638-13639.

[2] A. Granzhan, C. Schouwey, T. Riis-Johannessen, R. Scopelliti and K. Severin, J. Am. Chem. Soc. 2011, 133, 7106-7115.
Inorganic \& Coordination Chemistry

Synthesis and Characterisation of Chromium(III)-Complexes as possible Ionic Luminescent Material in Light Emitting Electrochemical Cells

\section{J. Schönle $^{1}$, E. C. Constable ${ }^{1}$, C. E. Housecroft}

${ }^{1}$ Department of Chemistry, University of Basel, Spitalstrasse 51, CH-4056 Basel

Light-emitting electrochemical cells (LEECs) are single-layer electroluminescent devices consisting of an ionic luminescent material sandwiched between two electrodes. Up to now, ionic ruthenium(II) and iridium(III) complexes as luminescent materials have been widely investigated with promising results. However, because of the small abundance of these elements in the Earth's crust these metals are very expensive. A possible alternative are chromium(III)-complexes, chromium is relatively abundant and therefore also much cheaper.

We present here the synthesis and characterisation of ionic chromium(III)complexes as hexafluoridophosphate salts. As ligands functionalised 2-2 bipyridine, 1,10-phenanthroline or 2,2 $: 6^{\prime}, 2^{\prime \prime}$-terpyridine and derivatives thereot were used.

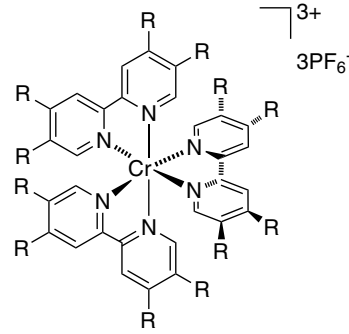

$\mathrm{R}=\mathrm{H}$ or $\mathrm{Me}$

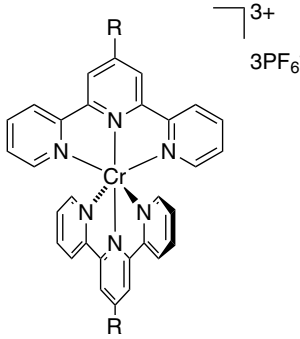

$\mathrm{R}=\mathrm{H}$ or 4-pyridyl
Inorganic \& Coordination Chemistry

The Use of Polypyridyl Ruthenium(II) and Copper(I) Complexes as Water Splitting Catalysts and in DSSCs

$\underline{\text { Jennifer A. Rudd }}^{1}$, E. C. Constable ${ }^{2}$, C. E. Housecroft ${ }^{2}$, M. Meuwly ${ }^{2}$, C. $\mathrm{Hill}^{3}$, I. Gueletti ${ }^{3}$, H. Lv ${ }^{3}$

${ }^{1}$ University of Basel, Spitalstrasse 51, 4056 Basel, Switzerland ${ }^{2}$ University of Basel, Klingelbergstrasse 80, 4056 Basel, Switzerland ${ }^{3}$ Emory University, Atlanta, GA 3022, USA

We are currently focusing attention on the use of transition metal complexes with bipyridine- and terpyridine-based ligands for applications in LEECs, DSSCs and as water-splitting catalysts. We are developing a series of functionalised 4'-pyridyl-2,2':6',2"-terpyridine ruthenium(II) complexes and examining their photophysical and electrochemical properties ${ }^{1}$, along with their water splitting activity. Use of a benzyl substituted complex gives the highest $\mathrm{O}_{2}$ yield (Fig 1).

We are also investigating heteroleptic bipyridine based copper(I) complexes as dye sensitisers in DSSCs which have promising efficiencies (Fig. 2$)^{2}$.

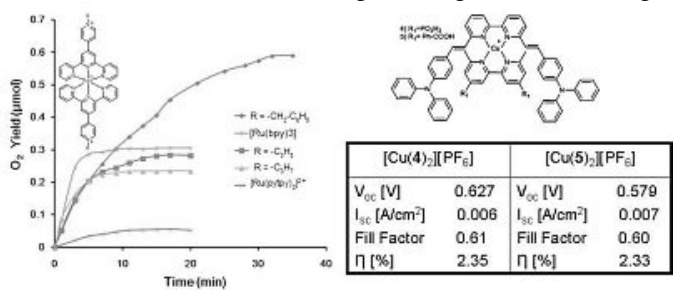

(Left) Water splitting activity using different $\mathrm{Ru}(\mathrm{II})$ complexes. (Right) Efficiencies of $\mathrm{Cu}(\mathrm{I})$ solar cells

[1] E.C. Constable, M. Devereux, E.L. Dunphy, C.E. Housecroft, J.A. Rudd, J.A. Zampese, Dalton Trans., 2011, 40, 5505-5515

[2] B. Bozic-Weber, V. Chaurin, E.C. Constable, C.E. Housecroft, M. Meuwly, M. Neuburger, J.A. Rudd, L. Siegfried, E. Schönhofer, manuscript in preparation
Inorganic \& Coordination Chemistry

$\mathrm{Zn}(\mathrm{II})$ and $\mathrm{Cu}(\mathrm{I})$ complexes for lighting and energy production devices

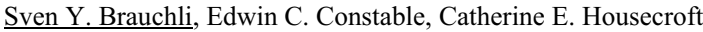

University of Basel, Spitalstrasse 51, CH-4056 Basel, Switzerland

With the growing world population, mankind is struggling with the increasing energy consumption on the one hand and with the growing emission of global warming gases on the other hand. Therefore it has become a globa ambition not only to save power by optimizing already existing energy sources and finding and inventing new ways for producing energy but also to reduce the emission of greenhouse gases as much as possible by implementing new devices on the market.

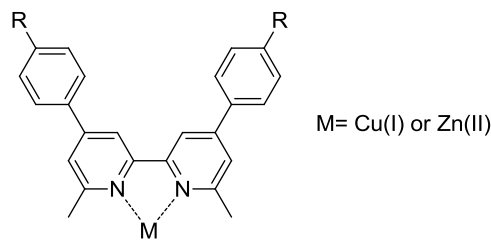

For this reasons zinc(II) and copper(I) complexes with 2,2'-bipyridine derivative ligands ${ }^{[1]}$ have been synthesized and tested on their applications as lighting and energy production devices.

[1] F. Kröhnke, Synthesis, 1976, 1. 
Inorganic \& Coordination Chemistry

Approaches to solid-state dye sensitized solar cells (DSSCs)

Ewald Schönhofer, Biljana Bozic-Weber, Edwin C. Constable and Catherine E. Housecroft

Department of Chemistry, University of Basel, Spitalstrasse 51, CH4056-Basel

The urge to find an alternative for the limited and often polluting non-sustainable fossil fuels on Earth is imminent. One of the most obvious solutions is the largest natural power source available to Earth, the Sun. To harness at least part of this vast amount of energy, much research is being conducted on solar cells. Dye sensitized solar cells (DSSCs) are particularly attractive due to their ease of fabrication and low costs compared with conventional silicon based photovoltaic devices. In liquid state DSSCs, a liquid and also volatile electrolyte is used, which causes stability problems. To address this problem, we are using solid-state hole conductors in place of the liquid electrolyte.

We are currently investigating the fabrication of solid state DSSCs based on copper(I) iodide and nanoparticulate $\mathrm{TiO}_{2}$. Progress in this field will be reported including the use of a variety of 2,2'-bipyridine-based anchoring ligands and copper(I) dyes.

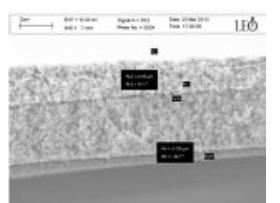

Layer structure of a solid state DSSC

Inorganic \& Coordination Chemistry

Copper(I) Complexes of Acyclic $P, N, N^{\prime}, P^{\prime}$-Ligands for Sustainable OLED-type Devices

Umut Soydaner, Edwin C. Constable, Catherine E. Housecroft

Dept. of Chemistry, University of Basel, Spitalstr. 51, CH-4056 Basel

Organic light-emitting devices (OLEDs) based upon transition metal or lanthanide metal emitters or sensitizers have attracted a great deal of attention due to their potential use in lighting as well as future panel display applications [1]. In recent years, copper(I) complexes showed promising results as a sustainable alternative to the traditionally adopted lanthanide emitters or sensitizers and the external quantum efficiency and up to $16 \%$ has been realized [2].

With the goal of optimizing light emitting properties of copper(I) complexes, we have synthesized a family of $P, N, N^{\prime}, P^{\prime}$-type ligands of the type shown below along with their mononuclear copper(I) complexes. The properties of these complexes and structure-property relationships will be presented.

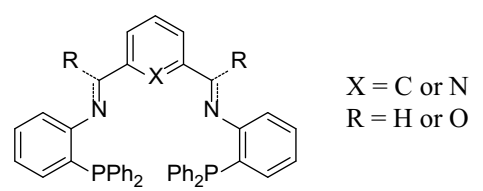

[1] M. A. Baldo, M. E. Thompson, S. R. Forrest, Pure Appl. Chem. 1999, $71,2095$.

[2] Q. Zhang, Q. Zhou, Y. Cheng, L. Wang, D. Ma, X. Jing and F. Wang, Adv. Funct. Mater. 2006, 16, 1203.
Inorganic \& Coordination Chemistry

Neocuproine Based Copper Dyes for Dye Sensitized Solar Cells

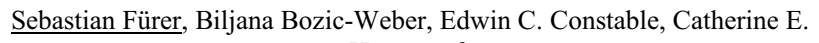
Housecroft

University of Basel, Spitalstrasse 51, CH-4056 Basel, Switzerland

Dye sensitized solar cells (DSSCs) are of great interest as a valuable alternative to the commercial silicon solar cells. Copper(I)-based dyes have shown promising performances in DSSCs and are interesting candidates for lowcost solar cells. A straight forward approach to obtain $\mathrm{TiO}_{2}$ bound heteroleptic copper(I) complexes was shown to be ligand exchange between homoleptic copper(I) complexes and $\mathrm{TiO}_{2}$ anchored 2,2'-bipyridine ligands [1].

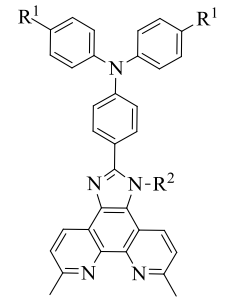

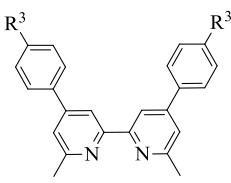

$\mathrm{R}^{1}, \mathrm{R}^{2}=$ alkyl chains

$\mathrm{R}^{3}=\mathrm{CO}_{2} \mathrm{H}, \mathrm{PO}_{3} \mathrm{H}_{2}$

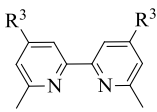

3
Homoleptic copper (I) complexes with neocuproine based ligands of type $\mathbf{1}$ are exchanged with anchoring ligands of type $\mathbf{2}$ and $\mathbf{3}$. The obtained heteroleptic complexes are tested in DSSCs using different liquid electrolytes to overcome stability problems and open circuit voltage limitations when using the $\mathrm{I}^{-} / \mathrm{I}_{3}^{-}$-electrolyte.

[1] B. Bozic-Weber, E.C. Constable, C.E. Housecroft, P. Kopecky, M. Neuburger, J.A. Zampese, Dalton Trans., 2011, 40, 12584.

Inorganic \& Coordination Chemistry

Ionic and neutral iridium(III) complexes for photonic applications

G. E. Schneider $^{1}$, M. Neuburger ${ }^{1}$, J. A. Zampese ${ }^{1}$, E. C. Constable ${ }^{1}$, C. E. Housecroft ${ }^{1}$, H. Bolink ${ }^{2}$

${ }^{1}$ Dept. of Chemistry, University of Basel, Spitalstr. 51, CH-4056 Basel ${ }^{2}$ Instituto de Ciencia Molecular, Universidad de Valencia, E-46980 Paterna

Light-emitting electrochemical cells (LEECs) and organic light emitting diodes (OLEDs) promise significant increases in efficiency as compared to typical fluorescent lighting. OLEDs and LEECs incorporate electroluminescent devices having an emissive layer usually composed of organic molecules. Compared to OLEDs, LEECs feature significantly simplified architecture that requires no encapsulation for protection from the environment. Two electrodes sandwich an emissive layer that contains light emitting molecules. Iridium(III) is often used as core atom in these emitting molecules.

A screening of further iridium(III) complexes has been done leading to new ionic as well as neutral compounds with different bipyridines as ligands, $\mathrm{L}_{1}$ and $\mathrm{L}_{2}$.

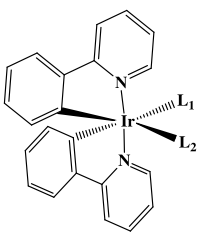

[1] H. J. Bolink, E. Coronado, R. D. Costa, E. Ortí, M. Sessolo, S. Graber, K. Doyle, M. Neuburger, C. E. Housecroft, E. C. Constable, Adv. Mater., 2008, 20, 1-4.

[2] S. Graber, K. Doyle, M. Neuburger, C. E. Housecroft, E. C. Constable, R. D. Costa, E. Ortí, D. Repetto, H. J. Bolink, J. Am. Chem. Soc., 2008, 130, 14944-14945. 
Inorganic \& Coordination Chemistry

Blue to Red: Emission Colour Tuning of Ir(III) complexes for Lightemitting Electrochemical Cells

\section{$\underline{\text { A. M. Bünzli }}{ }^{1}$, E. C. Constable ${ }^{1}$, C. E. Housecroft ${ }^{1}$, H. Bolink ${ }^{2}$, A. Pertegás ${ }^{2}$}

${ }^{1}$ Department of Chemistry, University of Basel, Spitalstrasse 51, CH-4056 Basel, Switzerland

${ }^{2}$ Instituto de Ciencia Molecular, Universidad de Valencia, 46980 Paterna, Spain

Octahedral iridium(III) complexes of the type $\left[\operatorname{Ir}\left(\mathrm{C}^{\wedge} \mathrm{N}\right)_{2}\left(\mathrm{~N}^{\wedge} \mathrm{N}\right)\right]\left[\mathrm{PF}_{6}\right]$ show promising properties for applications in light-emitting electrochemical cells (LEEC). Colour tuning of the electroluminescence can be achieved by either functionalizing the cyclometallating $\mathrm{C}^{\wedge} \mathrm{N}$ ligand or functionalizing the $\mathrm{N}^{\wedge} \mathrm{N}$ ancillary ligand or by combinatorial approaches of the two type of ligands considering the respective effect on the emission colour.

White light-emitting LEECs can be obtained by the combination of blue and orange emitters or in a three component system of blue, green and red emitters.
$\mathrm{N}^{\wedge} \mathrm{C}$<smiles>c1ccc(-c2cccs2)nc1</smiles><smiles>[R]c1ccc(-n2cccn2)cc1</smiles><smiles>[R]c1ccc(-n2cccn2)c([R])c1</smiles>
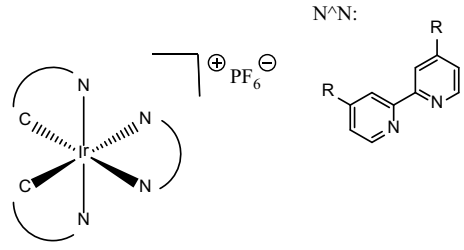

Herein we present the effect on the photoluminescence as well as on the electroluminescence of various $\left[\operatorname{Ir}\left(\mathrm{C}^{\wedge} \mathrm{N}\right)_{2}\left(\mathrm{~N}^{\wedge} \mathrm{N}\right)\right]\left[\mathrm{PF}_{6}\right]$ complexes by alternating the set of ligands. A series of blue to red-emitting iridium(III) complexes have been synthesized and their photophysical properties investigated. Promising candidates have been tested in LEEC devices.

Inorganic \& Coordination Chemistry

Humidity sensing and structure-properties relationships of bismuth phosphates

\section{Sheng ${ }^{1}$, L. L. Gu ${ }^{2}$, X. L. $\mathrm{Mo}^{2}$, G. R. Patzke ${ }^{1 *}$}

${ }^{1}$ Institute of Inorganic Chemistry, University of Zurich, Zurich, Switzerland

${ }^{2}$ Department of Material Science, Fudan University, Shanghai, China

In our previous work, we reported on different new types of bismuthcontaining humidity sensing materials such as Aurivillius-type $\mathrm{Bi}_{2} \mathrm{MO}_{6}(\mathrm{M}=$ $\mathrm{Mo}, \mathrm{W})$ nanosheets ${ }^{[1]}$ and $\mathrm{Bi}_{6} \mathrm{~S}_{2} \mathrm{O}_{15}$ nanowires ${ }^{[2]}$. As a follow-up study within our systematic investigation of humidity sensing bismuth-containing materials, phase pure cubic sillenite $\mathrm{Bi}_{\mathrm{x}} \mathrm{PO}_{\delta}(13 \leq \mathrm{x} \leq 16 ; \delta \sim 17-20)$ was synthesized via a one-step hydrothermal treatment ${ }^{[3]}$. The unique structural and diverse physico-chemical properties of sillenite-type materials, such as doping processes, thermal stability and catalytic/optical properties are in the focus of our current investigations.

We therefore studied structure, morphology, surface-to-volume ratio and thermal stability of cubic bismuth phosphate. Moreover, this sillenite-type phase was tested as humidity sensing material at selected relative humidity steps from $11 \%$ to $95 \%$ and compared to monoclinc bismuth phosphate. In spite of its extremely low surface-to-volume ratio $\left(0.2 \mathrm{~m}^{2} / \mathrm{g}\right)$, the sillenite type of bismuth phosphate displayed promising humidity sensing characteristics in terms of response/recovery behavior, response/recovery time and reproducibility. Capacitance values display a linear relationship over the whole range of humidity values, which points to promising potential for technical applications

[1] K. B. Zheng, Y. Zhou, L. L. Gu, X. L. Mo, G. R. Patzke, G. R. Chen, Sens. Actuators B 2010, 148, 240.

[2] Y. Zhou, J.-D. Grunwaldt, F. Krumeich, K. B. Zheng, G. R. Chen, J. Stötzel, R. Frahm, G. R. Patzke, Small 2010, 6, 1173.

[3] M. Sheng, L. L. Gu, R. Kontic, Y. Zhou, K.B. Zheng, G. R. Chen, X. L. Mo, G. R. Patzke, Sens. Actuators B 2012, doi:10.1016/j.snb.2012.03.030.
Inorganic \& Coordination Chemistry

Synthesis and Characterisation of Iridium(III) Complexes with Sulfurfunctionalised Cyclometallating Ligands

\section{D. Ertl $^{1}$, E. C. Constable ${ }^{1}$, C. E. Housecroft ${ }^{1}$}

${ }^{1}$ Department of Chemistry, University of Basel, Spitalstrasse 51, CH-4056 Basel

Light emitting electrochemical cells (LEECs) are solid state lighting devices consisting of a single emitting layer. The working principle of a LEEC depends on mobile ions within the device, allowing a simple device structure. Due to their excellent photophysical properties and easy colour tunability, iridium complexes have been studied intensely as phosphorescent emitters Charged iridium(III) complexes containing two cyclometallating and one ancillary ligand are suited for application in LEECs.

Sulfur-containing functional groups have been introduced to the cyclometallating ligands of the iridium(III) complexes. As ancillary ligands, 2,2'bipyridine (bpy) and substituted bpy derivatives have been used to study the effects of the introduced sulfur-containing moieties.

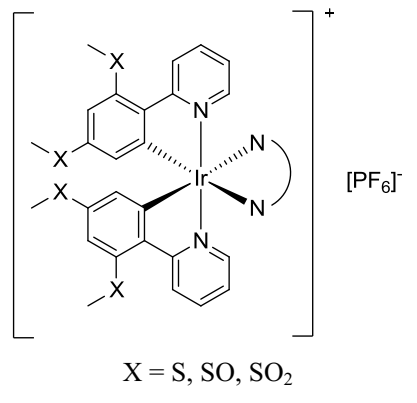

$\mathrm{N}^{\wedge} \mathrm{N}=$ bpy and bpy derivatives

Inorganic \& Coordination Chemistry

New Manganese containing Polyoxometalates for Water Oxidation

\section{Kim von Allmen, Greta R. Patzke*}

Institute of Inorganic Chemistry, University of Zurich,

Winterthurerstrasse 190, 8057 Zurich, Switzerland

Polyoxometalates (POMs) are structurally versatile oxoclusters, preferably of $\mathrm{Mo}, \mathrm{W}$ and $\mathrm{V}$ in their high oxidation states, with a wide spectrum of applications. Lacunary POM derivatives act as flexible ligands for the coordination of transition metal centers. The ability of transition metal-containing POMs to undergo multi-electron reduction processes renders them interesting catalysts for oxygen evolution reactions as a pathway to sustainable energy resources. Compared to organometallic compounds, POMs offer the advantage of ligand stability towards oxidative degradation. Ruthenium substituted sandwich-type POMs have shown promising performance as water oxidation catalysts (WOCs), and we have recently revealed POMphotosensitizer complexes as catalytically active species for $\mathrm{Ru}-$ and $\mathrm{Co}$ POMs. ${ }^{[1]}$ Although economic reasons restrain the industrial application of $\mathrm{Ru}-\mathrm{POMs}$, they serve as model compounds for further optimization of the active metal centers.

We perform systematic screening of lacunary POMs as chelating shells for manganese centers with the goal of deriving structure-activity guidelines for Mn-POMs as WOCs. Cobalt-containing POMs have furthermore been reported as WOCs. ${ }^{[2]}$ Unfortunately, their structural integrity may not be maintained during the catalytic process. ${ }^{[3]}$ We thus report on new strategies for POM stability tests and on immobilization techniques for POM-WOCs on various nanostructured carrier materials.

[1] P.-E. Car, M. Guttentag, K. K. Baldridge, R. Alberto, G. R. Patzke, Green Chem. 2012, DOI:10.1039/C2GC16646A

[2] Q. Yin, J. M. Tan, C. Besson,Y. V. Geletii, D. G. Musaev, A.E. Kuznetsov, Z. Luo, Hardcastle, C. L. Hill, Science 2010, 328, 342.

[3] J. J. Stracke, R. G. Finke, J. Am. Chem. Soc. 2011, 133, 14872 
Inorganic \& Coordination Chemistry

Novel Zn/Sb-containing polyoxometalates: crystal structures, modeling and catalytic studies

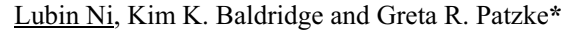

\section{Institute of Inorganic Chemistry, University of Zurich,} Winterthurerstrasse 190, CH-8057 Zurich, Switzerland

Polyoxometalates (POMs) are metal-oxygen clusters of early transition metals and they have a wide range of applications in catalysis, medicine, electrochemistry and materials science due to their tuneable chemical and physical properties. We present two new Zn-polytungstoantimonates $\alpha / \beta-\left[\mathrm{Zn}_{2} \mathrm{Sb}_{2}\left(\mathrm{ZnW}_{9} \mathrm{O}_{34}\right)_{2}\right]^{14-}(\alpha / \beta$-isomers $)$ as highly efficient catalysts for selective $\mathrm{H}_{2} \mathrm{O}_{2}$-assisted oxidation of alcohols. For the first time, crystallographic evidence for high-valent $\mathrm{Sb}(\mathrm{V})$-containing POM species involved in homogeneous alcohol oxidation processes is presented, and these compounds are verified with a wide range of analytical characterizations in combination with high level computational methods. The innovative introduction of $\mathrm{Sb}$ centers as a main group element into the metal belt region of sandwich-type POM catalysts opens up new mechanistic perspectives. This paves the way to chemically optimizing POMs for large-scale "green" catalytic and energy technology applications.

[1] (a) N. Mizuno, K. Yamaguchi, K. Kamata, Coord. Chem. Rev. 2005, 249 , 1944. (b) K. Kamata, K. Yonehara, Y. Nakagawa, K. Uehara, N. Mizuno, Nature Chem. 2010, 2, 478. (c) D. Sloboda-Rozner, P. Alsters, R. Neumann, J. Am. Chem. Soc. 2003, 125, 5280.

[2] L. Ni, K. K. Baldridge, G. R. Patzke, submitted.
Inorganic \& Coordination Chemistry

$\mathrm{BiVO}_{4}$ as Visible-Light Driven Photocatalyst: Influence of Mo Substitution vs. $\mathrm{TiO}_{2}$ and $\mathrm{SnO}_{2}$ Heterojunctions

\section{Roman Kontic, Greta R. Patzke*}

University of Zurich, Winterthurerstr. 190, CH-8057 Zürich, Switzerland

New solutions are required to satisfy the need for sustainable energy and clean water of tomorrow's society. Applications of semiconductor nanoparticles, such as photocatalytic water splitting to produce $\mathrm{H}_{2}$ and $\mathrm{O}_{2}$ or the photocatalytic degradation of organic pollutants, promise an answer to that urgent request. [1]

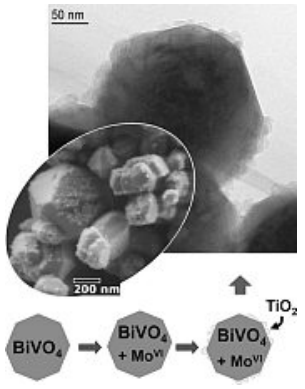

We present a systematic study on the influence of several parameters on the photocatalytic activity of hydrothermally synthesized $\mathrm{BiVO}_{4}[2]$. Our investigations on factors influencing the catalyst activity cover multiple parameters and combinations, e.g. Mo substitution, calcination at $500{ }^{\circ} \mathrm{C}$, and surface modification with $\mathrm{TiO}_{2}$ and $\mathrm{SnO}_{2}$.

To analyze the photocatalyst properties and performance, we applied PXRD, SEM, TEM, BET surface analysis, UV/vis spectroscopy, and photocatalytic measurements for methylene blue degradation and $\mathrm{O}_{2}$ production.

The results are discussed in view of different $\mathrm{BiVO}_{4}$ applications in waste water purification and water splitting for clean solar energy.

[1] Y. Zhou, K. Vuille, A. Heel, B. Probst, R. Kontic, G. R. Patzke, Appl. Catal. A 2010, 375, 140.

[2] R. Kontic, G. R. Patzke, J. Solid State Chem. 2012, DOI: 10.016/j.jssc.2011.11.050
Inorganic \& Coordination Chemistry

Photocatalytic Water Oxidation with Cobalt-containing Polyoxometalates

\section{Fabio Evangelisti, Greta R. Patzke*}

Institute of Inorganic Chemistry, University of Zurich, Winterthurerstrasse 190, 8057 Zurich, Switzerland

Co-containing polyoxometalates show promising activity as water oxidation catalysts (WOCs) for the more complex half reaction of water splitting. ${ }^{[1]} \mathrm{A}$ major research challenge is the mechanistic clarification of this process, especially for Co-POMs, which have raised discussions about catalyst stability and active species involved. ${ }^{[2]}$ We screen carbon-free Co-POMs prepared from readily available heteropolyanions (e.g. Keggin $\left[\mathrm{X}-\mathrm{M}_{12} \mathrm{O}_{40}\right]^{\mathrm{n}-}$ and Well-Dawson $\left[\mathrm{X}_{2}-\mathrm{M}_{18} \mathrm{O}_{62}\right]^{\mathrm{n}-}$ moieties) for derivative formation and WOC activity. In search of structure-activity relationships, we focus on the influence of the hetero- $\mathrm{X}$ substituent ( $\mathrm{X}=\mathrm{P}, \mathrm{Si}$ and $\mathrm{Sb}, \mathrm{Bi}, \mathrm{Ge}, \mathrm{Mo}, \mathrm{Co}$ as more explorative options). Co-POMs with different Co nuclearities are synthesized to derive guidelines for WOC construction

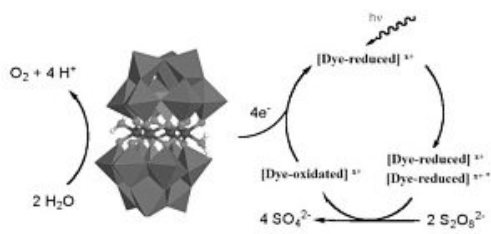

Visible-light-driven WOC experiments are carried out and optimized using the new Co-POMs, novel photosensitizers, and a sacrificial oxidant.

[1] P.-E. Car, M. Guttentag, K. K. Baldridge, R. Alberto, G. R. Patzke, Green Chem. 2012, DOI:10.1039/C2GC16646A.

[2] J. J. Stracke, R. G. Finke, J. Am. Chem. Soc. 2011, 133, 14872.
Inorganic \& Coordination Chemistry

Kinetics and phase formation law of high-temperature nitridation of tantalum under isothermal conditions $\underline{\text { Heghine N. Stepanyan }}^{1}$, Suren L. Kharatyan ${ }^{1,2}$

${ }^{1}$ Yerevan State University, 1, A. Manoukyan Str., Yerevan, Armenia ${ }^{2}$ A.B. Nalbandyan Institute of Chemical Physics NAS RA 5/2, P.Sevak Str., Yerevan, Armenia

The technological processes of refractory metals nitrides synthesis by selfpropagating high-temperature synthesis (SHS) methods processed at high temperatures with very high rate. To control and to optimize such processes it is necessary to investigate the mechanism and kinetics of interaction in conditions of synthesis (high temperature, high pressure and short times). In the present work the nitridation kinetics of tantalum and phase composition of products were studied in a wide temperature range $\left(1800-2400^{\circ} \mathrm{C}\right)$ and at 1-10 atm nitrogen pressure. The investigation were carried out by using High Speed Scanning Electrothermography (HS SET) method, which allows rapidly interrupting the interaction by quenching of samples (by the rate up to $3 \cdot 10^{4} \% \mathrm{~s}$ ). As initial reagents were used $100 \mu \mathrm{m}$ in diameter tantalum wires $(99.98 \%$ ) and gaseous nitrogen $(99.99 \%)$. The wires were heated by passing direct electric current. Duration of experiments vary from $0.05 \mathrm{~s}$ up to $10 \mathrm{~s}$. The reacted samples were examined by various physicochemical methods (gravimetric, metallographic, XRD-analysis, SEM), which allow to track the phase formation mechanism and the process of kinetics.

It was established that:

1. Nitrogen-rich TaN phase have formed at $5 \mathrm{~atm}$ and $2000^{\circ} \mathrm{C}$ temperature conditions, but [1] authors have shown, that at the same temperature this phase is formed at 10 and higher atmosphere of nitrogen;

2. Kinetics of tantalum nitridation isn't described by well-known parabolic law under investigated conditions. This process occurs in transition zone of kinetic regime to diffusion regime.

[1] H. Wiesenberger, W. Lengauer, P. Ettmayer, Acta Mater. 1998, Vol.46, No.2, 651-666 
Inorganic \& Coordination Chemistry

Determination of the NMR Parameters for in situ $\mathrm{pH}$ and Quantitative Concentration Measurements of $\mathrm{HCOOH} / \mathrm{CO}_{2}$ Systems Under Pressure

\author{
Séverine Moret, Paul J. Dyson, Gábor Laurenczy
}

Laboratory of Organometallic and Medicinal Chemistry (LCOM), École Polytechnique Féderale de Lausanne (EPFL), BCH, 1015 Lausanne, Switzerland, Email: severine.moret@epfl.ch

One of the main challenges of our time is to have a convenient energy supply from renewable sources. In this context hydrogen is among the candidates as an energy carrier for mobile applications and $\mathrm{HCOOH}$ has been proposed as a hydrogen storage material. Recently catalysts that liberate $\mathrm{H}_{2}$ from formic acid have been developed. ${ }^{[1]}$ The reverse reaction, i.e. $\mathrm{H}_{2}$ storage in formic acid/formate from the hydrogenation of carbonate, bicarbonate and carbon dioxide are also under investigation. ${ }^{[2,3]}$

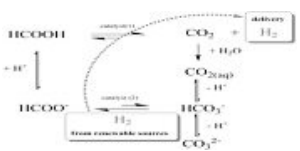

High-pressure sapphire NMR spectroscopy is useful for the study of these reactions up to pressures of 100 bar. $^{[4]}$ Nevertheless, an improvement of was found to be necessary to obtain quantitative, qualitative and structural information in the reaction mixtures. All the necessary NMR parameters have been determined, as have in situ $\mathrm{pH}$ measurements, as well as quantitative measurements for all the concentrations $\left(\mathrm{HCOOH}, \mathrm{HCOO}^{-}, \mathrm{CO}_{3}{ }^{2-}\right.$, $\mathrm{HCO}_{3}^{-}, \mathrm{CO}_{2}, \mathrm{H}_{2}$ and catalysts) are possible.

Acknowledgements: We thank EOS Holding and EPFL for financial support

[1] C. Fellay, P. J. Dyson, G. Laurenczy, Angew. Chem. Int. Ed., 2008, 47, 3966.

[2] G. Laurenczy, F. Joo, L. Nadasdi, Inorg. Chem., 2000, 39, 5083.

[3] C. Federsel, R. Jackstell, A. Boddien, G. Laurenczy, M. Beller; ChemSusChem, 2010, 3 , 1048 .

[4] A. Cusanelli, U. Frey, D. T. Richens, A. E. Merbach, JACS, 1996, 118, 5265.

Inorganic \& Coordination Chemistry

Mechanistic study: Catalyst activation in formic acid dehydrogenation reactions

Ewan Frost-Pennington, Weijia Gan, Gábor Laurenczy*

Institute of Chemical Sciences and Engineering, Laboratory of Organometallic and Medicinal Chemistry, École Polytechnique Fédérale de Lausanne (EPFL), Switzerland. Email: ewan.frost-pennington@epfl.ch

There are many benefits offered using $\mathrm{H}_{2}$ as an energy vector. The selective homogeneous catalytic decomposition of the formic acid could be used as a safe and convenient way to generate $\mathrm{H}_{2}{ }^{[1]}$ Mechanisms and catalytic cycles are proposed for these reactions using the $\mathrm{Ru}(\mathrm{II})$-TPPTS precatalysts. ${ }^{[2]}$

In the first, activation cycle, several precatalysts showed superior initial reaction rates on $\mathrm{H}_{2}$ production. After, as the kinetic traces show, the reaction rate becomes constant, the same active species are formed in all systems. ${ }^{[1]}$

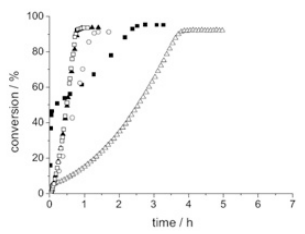

Figure 1. Kinetic traces of pre-catalyst $\mathrm{RuCl}_{3} \cdot \mathrm{xH}_{2} \mathrm{O}$ with TPPTS. 1st (-), 3rd (०), 5th ( $\mathbf{\Lambda}$ ) cycle compared to $1 \mathrm{st}(\Delta)$ and $3 \mathrm{rd}(\square)$ cycle of $\left[\mathrm{Ru}\left(\mathrm{H}_{2} \mathrm{O}\right)_{6}\right][\text { tos }]_{2}$. TPPTS, $4 \mathrm{M} \mathrm{HCOOH} / \mathrm{HCOONa}, 2.5 \mathrm{~m}$ $\mathrm{H}_{2} \mathrm{O} / \mathrm{D}_{2} \mathrm{O}(1: 1), 90^{\circ} \mathrm{C}$, addition of $0.38 \mathrm{ml} \mathrm{HCOOH}$ for recycling. ${ }^{[1]}$

Our recent results, using ${ }^{1} \mathrm{H},{ }^{13} \mathrm{C},{ }^{31} \mathrm{P}$ NMR and UV-Vis spectroscopies, offer an insight into the catalyst activation step, information on the first reaction cycle.

Acknowledgment: The Swiss National Science Foundation and EPFL are thanked for financial support

[1] C. Fellay, P. J. Dyson, G. Laurenczy, Angew. Chem. Int. Ed., 2008, 47, 3966.

[2] C. Fellay, N. Yan, P. J. Dyson, G. Laurenczy, Chem. Eur. J., 2009, 15, 3752
Inorganic \& Coordination Chemistry

Ruthenium-Catalyzed Hydrogen Generation from Formic Acid using Oligocationic, Ammoniomethyl-substituted Triarylphosphine Ligands

Weijia Gan, Dennis J. M. Snelders, Paul J. Dyson, Gábor Laurenczy*

Institute of Chemical Sciences and Engineering, Laboratory of Organometallic and Medicinal Chemistry, École Polytechnique Fédérale de Lausanne (EPFL), Switzerland. Email: weijia.gan@epfl.ch

The appeal of $\mathrm{HCOOH}$ as a vector to store $\mathrm{H}_{2}$ lies in its simplicity and consequently the dehydrogenation of $\mathrm{HCOOH}$ or its salts are important processes for mobile applications. Successful examples of highly active and selective homogeneous catalytic systems include $\mathrm{Ru}^{[1,2]}$ and $\mathrm{Fe}^{[3]}$ catalysts with neutral or anionic phosphine ligands.

We have recently explored the Ru-catalyzed $\mathrm{H}_{2}$ generation from $\mathrm{HCOOH}$ using a series of oligocationic phosphines ${ }^{[4]}$ as ligands in aqueous solution (example shown in Scheme 1), in the absence of amines or other additives, under mild reaction conditions. Excellent reaction rates and highly stable catalysts were obtained.

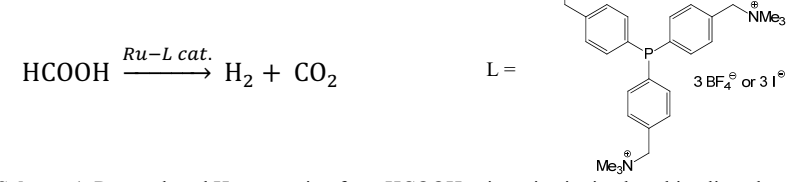

Scheme 1. Ru-catalyzed $\mathrm{H}_{2}$ generation from $\mathrm{HCOOH}$ using tricationic phosphine ligands

Acknowledgment: The Swiss National Science Foundation and EPFL are thanked for financial support.

[1] C. Fellay, P. J. Dyson, G. Laurenczy, Angew. Chem. Int. Ed., 2008, 47, 3966.

[2] W. Gan, C. Fellay, P. J. Dyson, G. Laurenczy, J. Coord Chem 2010, 63, 2685.

[3] A. Boddien, D. Mellmann, F. Gartner, R. Jackstell, H. Junge, P. J. Dyson, G. Laurenczy, R. Ludwig, M. Beller, Science, 2011, 333, 1733 .

[4] D. J. M. Snelders, C. van der Burg, M. Lutz, A. L. Spek, G. van Koten, R. J. M. K. Gebbink, Chem CatChem, 2010, 2, 1425.

Mechanistic Studies on the Hydride Formation during the Formic Acid Dehydrogenation, Catalysed by Ruthenium(II) - Cationic Phosphines.

$$
\text { Arnaud Thevenon, Weijia Gan, Gábor Laurenczy }{ }^{*}
$$

Institute of Chemical Sciences and Engineering, Laboratory of Organometallic and Medicinal Chemistry, École Polytechnique Fédérale de Lausanne (EPFL), Switzerland. Email: anaud.thevenon@epfl.ch

The use of hydrogen for mobile applications is mainly limited by storage/delivery problems. Recent results showed that formic acid $(\mathrm{HCOOH})$ could be a suitable solution for hydrogen generation. ${ }^{1}$ The homogenous catalytic $\mathrm{HCOOH}$ decomposition reactions, using $\mathrm{Ru}(\mathrm{II})$ with anionic ${ }^{2}$ and neutral water-soluble phosphines, have been investigated in detail. ${ }^{3}$

Previous studies on the reaction mechanism of $\mathrm{HCOOH}$ cleavage have shown that important intermediates in the catalytic cycle are negatively charged. Thus the use of cationic soluble phosphines ${ }^{4}$ might help for the hydride complex formations. Our goal is to identify and characterise these hydride species in the reaction mixture, determine their influence on the rate and mechanism of this reaction. These catalytically active hydrides, formed in situ from $\mathrm{RuCl}_{3}$ and from respectively mono, tri and hexacationic phosphines in the reaction mixtures, can be synthetized also under hydrogen gas pressure and can be characterised in high-pressure sapphire tubes by multinuclear NMR spectroscopy.

Acknowledgment: The Swiss National Science Foundation and EPFL are thanked for financial support.

[1] C. Fellay, P. J. Dyson, G. Laurenczy, PCT Int. Appl. (2006), 36pp. CODEN: PIXXD2 WO 2008047312 A1 20080424 AN 2008:502691.

[2] W. Gan, C. Fellay, P. J. Dyson, G. Laurenczy, J. Coord. Chem., (2010), 63, 2685-2694.

[3] C. Fellay, N. Yan, P. J. Dyson, G. Laurenczy, Chem. Eur. J., (2009), 15, 3752 3760 .

[4] D. J. M. Snelders, C. van der Burg, M. Lutz, A. L. Spek, G. van Koten, R. J. M. K. Gebbink, ChemCatChem, (2010), 2, 1425-1437. 
Inorganic \& Coordination Chemistry

Synthesis and Properties of a Model Complex for the Cofactor F430

\section{David Witmer, Bernhard Jaun}

Laboratorium für Organische Chemie, ETH Zürich, Wolfgang Pauli-Strasse 10, 8093 Zürich

Cofactor F430 is the prosthetic group in the enzyme methyl-coenzyme reductase (MCR) catalyzing the key step in methanogenesis, the formation of methane $^{1}$. The reverse reaction, the anaerobic oxidation of methane (AOM), occurs in nature assisted by the same enzyme. The mechanism of the reaction has remained elusive despite intense investigations.

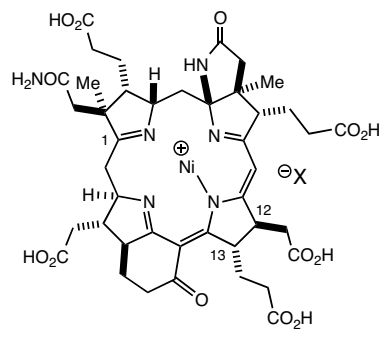

F430

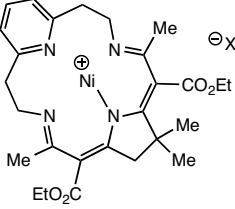

model complex
In order to help understanding the relationship of the structure and the fascinating reactivity of $\mathrm{F} 430$, a model complex was synthesized. The model complex represents a new class of F430 models as it combines key features like a similar chromophore with a simple, achiral structure, that allows the tuning of the properties by changing the peripheral substituents. The synthesis and properties of the model complex will be presented together with DFT-studies comparing the two structures from a computational point of view.

[1] (a) Thauer, R. K. Microbiology 1998, 144, 2377(b) Jaun, B.; Thauer, R. K. Metal Ions in Life Sciences 2007, 2, 323.

Metal-ion complexation and protonation of polyaromatic tridentate nitrogen- containing ligands producing six- and/or five-membered chelate rings.

Thi Nhu Y Hoang ${ }^{1}$, Timothée Lathion ${ }^{1}$, Marie Humbert-Droz ${ }^{1}$, Laure Guénée $^{2}$, Emmanuel Terazzi $^{1}$, Claude Piguet ${ }^{* 1}$

${ }^{1}$ Department of Inorganic and Analytical Chemistry, University of Geneva, 30 quai E. Ansermet, CH-1211 Geneva, Switzerland.

${ }^{2}$ Laboratory of Crystallography, University of Geneva, 24 quai E. Ansermet, CH-1211 Geneva 4, Switzerland.

We present the synthesis of a novel semi-rigid polyaromatic tridentate chelate ligand (L1) (Figure 1) and the preliminary studies of its complexation properties with proton and metals of variable sizes. Since $\mathbf{L 1}$ form adjacent six- and five-membered chelate rings, it is of interest for selective metal-ion complexation. Ligand $\mathbf{L 1}$ and its analogues fused-6-membered 2,6bis(azaindol-yl)pyridine (L2) [1] and 2,6-bis(8-quinolin-yl)pyridine (L3) [2] surprisingly show strong affinities for protons compared to the standard tridentate fused 5-membered 2,2';6', 2' '-terpyridine chelate (L4). The successive protonation steps occurring in $\mathbf{L 1}, \mathbf{L 2}, \mathbf{L 3}$ and $\mathbf{L} 4$ have been thoroughly investigated in the solid state and in solution.

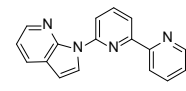

L1

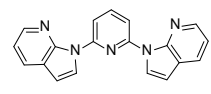

L2

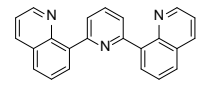

L3

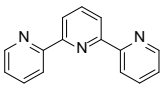

L4
Figure 1: Structure of the polyaromatic tridentate chelate ligands.

[1] Garner, K. L.; Parkes, L. F.; Piper, J. D.; Williams, J. A. G. Inorg. Chem. 2010, 49, 476.

[2] Jäger, M.; Eriksson, L; Bergquist, J; Johansson, O. J. Am. Chem. Soc. 2007, 72, 10227.
Inorganic \& Coordination Chemistry

Encapsulation of antimicrobial compounds into $\mathrm{SiO}_{2}$ nanocontainers

\section{Magdalena Priebe, Katharina M. Fromm}

University of Fribourg, Chemistry Department, Chemin du Musée 9, CH-1700 Fribourg, Switzerland

Nanometer sized hollow spheres, called nanocontainers exhibit an emerging potential as they can be used as drug carriers, reactors, confined reaction vessels, etc. Not only guest molecules can be enclosed inside their empty interior, but the shell of the capsule also provides additional protection $[1,2]$. The microemulsion method approach is superior to the traditional methods since micelles are used instead of solid templates. Reaction between reagents on the boundary phase between a micelle and the surrounding phase leads to the formation of a nanocontainer [3].

The purpose of this project is an encapsulation of an antimicrobial compounds, such as silver coordination polymer or silver nanoparticles inside silica nanocapsules (Figure 1). The characterization of nanocontainers is carried out using TEM, HRSEM, EDS, XRPD and DLS. The incorporation process will be followed by TGA as well as IR, and silver release will be determined using ICP.

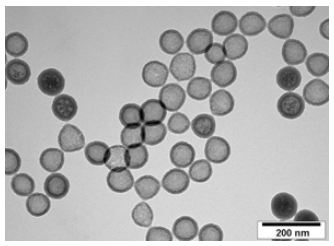

Figure 1. TEM image of $\mathrm{SiO}_{2}$ hollow spheres.

[1] Mou C.-Y. et al, Chem. Commun., 2009, 3542.

[2] Mou C.-Y. et al, J. Mater. Chem., 2011, 21, 789.

[3] Feldmann C. et al, Adv. Mater., 2009, 21, 1586.

\section{Evidence of ionic liquid crystal properties for a $\mathrm{DODA}^{+}$salt of the} keplerate $\left[\mathrm{Mo}_{132} \mathrm{O}_{372}\left(\mathrm{CH}_{3} \mathrm{COO}\right)_{30}\left(\mathrm{H}_{2} \mathrm{O}\right)_{72}\right]^{42-}$

Emmanuel Terazzi*1 ${ }^{1}$, Sébastien Floquet ${ }^{* 2}$, Akram Hijazi $^{3}$, Laure Guénée ${ }^{1}$, Claude Piguet ${ }^{1}$, Emmanuel Cadot $^{2}$

${ }^{1}$ Department of Inorganic and Analytical Chemistry,

University of Geneva, 30 quai E. Ansermet, CH-1211 Geneva, Switzerland.

${ }^{2}$ Institut Lavoisier de Versailles, University of Versailles

Saint-Quentin, 45 av. des Etats-Unis, 78035 Versailles, France.

${ }^{3}$ Lebanese University, Doctoral School of Science and Technology,

Research Platform for Environmental Science, Beirut, Lebanon.

Liquid crystals constitute a fascinating example of functional self-assembled materials. Incorporation of inorganic components into liquid crystalline phases appears particularly relevant for the elaboration of synergistic multifunctional materials according to a "bottom-up" approach. To date, a large number of metallomesogens have been prepared by chemical integration of metal ions into organic ligands. Polyoxometalates (POM), often described as polyanionic molecular oxides, exhibit a number of properties in all domains of chemistry. In this contribution, we present preliminary results obtained with the keplerate [1] (DODA) $)_{36}\left(\mathrm{NH}_{4}\right)_{6}\left[\mathrm{Mo}_{132} \mathrm{O}_{372}\left(\mathrm{CH}_{3} \mathrm{COO}\right)_{30}\right.$ $\left(\mathrm{H}_{2} \mathrm{O}\right)_{72}$, which exhibits ionic liquid crystalline properties at room temperature.[2]

[1] A. Müller, E. Kriekmeyer, H. Bögge, M. Schmidtmann, F. Peters, Angew, Chem., Int. Ed. 1998, 37, 3359.

[2] S. Floquet, E. Terazzi, A. Hijazi, L. Guénée, C. Piguet, E. Cadot, New J. Chem. 2012, 36, 865 . 
Inorganic \& Coordination Chemistry

Thermodynamic behavior of $\beta$-diketonates complexes in solution

$$
\underline{\text { Amir Zaim }}^{1} \text {, Homayoun Nozary }{ }^{1}, \text { Laure Guénée }^{2}, \text { Claude Piguet }^{1}
$$

${ }^{1}$ University of Geneva, Department of Inorganic and Analytical Chemistry, 30 quai E. Ansermet, CH-1211 Geneva 4, Switzerland.

${ }^{2}$ University of Geneva, Laboratory of Crystallography, 24 quai E. Ansermet, CH-1211 Genève 4, Geneva Switzerland.

Lanthanide(III) $\beta$-diketonates are among the most thoroughly investigated classes of coordination compounds for both their easy synthesis and the variety of their practical applications as NMR shift reagents, catalysts and sensing/probing devices [1]. Herein, a series of new lanthanide complexes has been synthesized by treating bent aromatic tridentate binding units with fluorinated lanthanide $\beta$-diketonates $\left[\mathrm{Ln}(\mathrm{hfa})_{3}\right.$ (diglyme)] (hfa $=$ hexafluoroacetylacetonate). Surprisingly, lanthanide(III) $\beta$-diketonates complexes behave differently with the 2,6-bis-(benzimidazol-2-yl)pyridine (NNN) (L1) and 6-(1-ethyl-1H-benzimidazole-2-yl)-pyridine-2-carboxylic acid diethylamide (NNO) (L2) tridentate ligands. In this contribution we discuss the speciation of mononuclear $\left[\mathrm{Ln}(\mathrm{L} k)(\mathrm{hfac})_{3}\right](k=1,2)$ and extended dinuclear $\left[\mathrm{Ln}_{2}(\mathrm{~L} 3)(\mathrm{hfac})_{6}\right]$ and trinuclear $\left[\mathrm{Ln}_{3}(\mathrm{~L} 4)(\mathrm{hfac})_{9}\right]$ complexes in organic solvents, together with their structural properties.
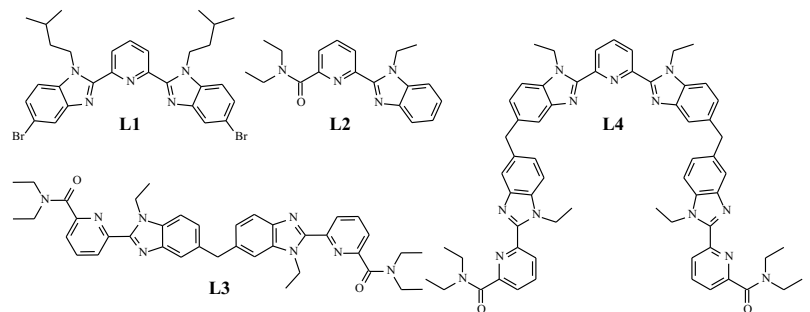

[1] Binnemans, K, Handbook on the Physics and Chemistry of Rare Earths. North-Holland publishing, 2005, 35, chap 225.
Inorganic \& Coordination Chemistry

Recent Advances in the Synthesis of High Oxidation State Palladium Trifluoromethyl Complexes

\section{E. Maennel, A. Togni*}

Department of Chemistry and Applied Biosciences, Swiss Federal Institute of Technology, ETH Zürich, CH-8093 Zürich, Switzerland

Palladium(IV) trifluoromethyl compounds have recently attracted broad attention as they have been proposed to be intermediates in various palladium catalyzed trifluoromethylation reactions.$^{[1]}$ They have been mostly accessible via transfer reactions of e.g. Pd(IV)-fluoride precursors with $\mathrm{TMSCF}_{3}$ or via oxidation of $\mathrm{Pd}(\mathrm{II})-\mathrm{N}$-aryl-ligated precursors in the presence of the hypervalent iodine(III) reagent $1 .^{[2]}$ The $\mathrm{Pd}(\mathrm{IV})$-product of the latter reaction is the first such species to be generated using a " $\mathrm{CF}_{3}{ }^{+}$" source and will reductively eliminate an aryl- $\mathrm{CF}_{3}$ compound upon heating.

Towards trifluoromethylation of allylic systems via a Pd(II)-catalyzed oxidative addition-reductive elimination process, various reactions of allyl$\mathrm{Pd}(\mathrm{II})$-ligand complexes with 1 have been investigated. Currently,

$\left[\mathrm{Pd}(\mathrm{II})(\right.$ allyl $\left.) \mathrm{Bpz}_{4}\right]$ derivatives appear to be the most promising precursors as they will react with 1 to give $\mathrm{Pd}-\mathrm{CF}_{3}$ species that are presumably of the type 3 and have been identified by ${ }^{19} \mathrm{~F}$ NMR. However, these complexes tend to readily decompose at room temperature in solution.

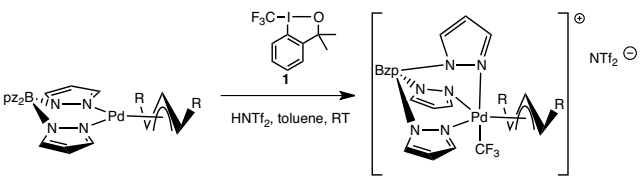

[1] Mu, X.; Wu, T.; Wang, H.; Guo, Y.; Liu, G. J. Am. Chem. Soc. 2012, 134, 878-881

[2] Ye, Y.; Ball, N.D.; Kampf, J.W.; Sanford, M. S. J. Am. Chem. Soc. 2010, 132, 14682-14687
Inorganic \& Coordination Chemistry

Synthesis, Crystal Structure and Magnetic Properties of $\mathbf{E u}_{5+\mathrm{x}} \mathbf{M g}_{18-\mathrm{x}} \mathrm{Si}_{13}$ Phases

\section{Adam Slabon, Christof Kubata and Reinhard Nesper ${ }^{*}$}

\section{ETH Zürich, Wolfgang-Pauli-Str. 10, CH-8093 Zürich}

The new ternary $\mathrm{Eu}_{5+\mathrm{x}} \mathrm{Mg}_{18-\mathrm{x}} \mathrm{Si}_{13}$ phase $(0.6<\mathrm{x}<2.4)$ has been obtained by solid-state synthesis and the crystal structure determined by Single-Crystal $\mathrm{X}$-Ray Diffraction. The compound crystallizes in the hexagonal crystal system (space group P62m, No. 189) and can be described according to the Zintl-Klemm concept as $\left(\mathrm{Eu}^{2+}\right)_{5+x}\left(\mathrm{Mg}^{2+}\right)_{18-\mathrm{x}}\left(\mathrm{Si}^{4-}\right)_{9}\left(\mathrm{Si}_{4}{ }^{10-}\right)$. The ternary silicides $\mathrm{Eu}_{5+\mathrm{x}} \mathrm{Mg}_{18-\mathrm{x}} \mathrm{Si}_{13}$ belong to the $\mathrm{M}_{5+\mathrm{x}} \mathrm{Mg}_{18-\mathrm{x}} \mathrm{X}_{13}$ structure family ( $\mathrm{M}=$ $\mathrm{Ba}, \mathrm{Sr} ; \mathrm{X}=\mathrm{Ge}, \mathrm{Si}$ ) [1] and contain two different types of anions: isolated $\mathrm{Si}^{4-}$ and planar $\mathrm{Si}_{4}$-clusters [2]. The cluster is coordinated by a trigonal prismatic arrangement of europium atoms, being often a source of frustrated magnetic interactions in Zintl phases [3]. A feature of the structure is the mixed occupancy of magnesium and europium in the $3(f)$ - site. This fact allows to study the dependency of the magnetic behavior on the europium content.

[1] R. Nesper, S. Wengert, F. Zuercher, A. Currao, Chem. Eur. J. 1999, $5,3382-3389$.

[2] R. Nesper, Prog. Solid St. Chem. 1990, 29, 1-45.

[3] E. Cuervo Reyes, A. Slabon-Turski, C. Mensing, R. Nesper, J. Phys. Chem. C 2012 116, 1158-1164.
Inorganic \& Coordination Chemistry

Improving Emission Quantum Yields of Gold(III) Triplet Phosphors

Michael Bachmann, Olivier Blacque and Koushik Venkatesan*

Institute of Inorganic Chemistry, University of Zürich, Winterthurerstrasse 190, CH-8057, Zürich, Switzerland

Recently, organometallic $\mathrm{Au}(\mathrm{III})$ complexes are gaining intense interest as luminescent materials for potential applications in PhOLEDs. ${ }^{[1]}$ We have recently reported cyclometalated $\mathrm{Au}(\mathrm{III})$ complexes bearing aryl and alkyne as ancillary ligands that possess reasonable stability and display room temperature phosphorescence. ${ }^{[2]}$ The origin of the emission in most of these complexes is ascribed to intra-ligand charge transfer $\left({ }^{3}\right.$ ILCT) with limited participation of the gold center in the excited state up until now. In this current work, we employ new strategies to increase the involvement of the gold centre in the excited state to achieve complexes that have excellent quantum yield.

[1] Wong, K. M. -C.; Hung, L. -L.; Lam, W. H.; Zhu, N.; Yam, V. W. -W. J. Am Chem. Soc. 2007, 129, 4350.

[2] (a) Garg, J. A.; Blacque, O.; Fox, T.; Venkatesan, K. Inorg. Chem. 2010, 49 , 11463. (b) Garg, J. A.; Blacque, O.; Venkatesan, K. Inorg. Chem. 2011, 5430. 
Inorganic \& Coordination Chemistry

\section{Investigations into Neutral Gold(III) Triplet Phosphors}

Alexander Szentkuti, Olivier Blacque and Koushik Venkatesan*

Institute of Inorganic Chemistry, University of Zürich, Winterthurerstrasse 190, CH-8057, Zürich, Switzerland

Organometallic $\mathrm{Au}(\mathrm{III})$ complexes have been less explored as luminescent materials due to their instability attributed generally to the low-energy d-d ligand field (LF) states, which are responsible for the quenching of the luminescent excited states at room temperature and the high electrophilic character of the $\mathrm{Au}(\mathrm{III})$ center ${ }^{[1]}$ We have recently reported cyclometalated $\mathrm{Au}(\mathrm{III})$ complexes bearing aryl and alkyne as ancillary ligands that are reasonably stable and display room temperature phosphorescence. ${ }^{[2]}$ However, the complexes poses several limitations for applicability in light emitting devices. ${ }^{[2]}$ In this current work, we have tried to employ several strategies to achieve complexes with suitable ligands that provide excellent thermal and photo-stability with readily tunable emission properties. ${ }^{[3]}$

[1] Wong, K. M. -C.; Hung, L. -L.; Lam, W. H.; Zhu, N.; Yam, V. W. -W. J. Am Chem. Soc. 2007, 129, 4350 .

[2] (a) Garg, J. A.; Blacque, O.; Fox, T.; Venkatesan, K. Inorg. Chem. 2010, 49 11463. (b) Garg, J. A.; Blacque, O.; Venkatesan, K. Inorg. Chem. 2011 5430.

[3] Szentkuti, A.; Garg, J. A.; Venkatesan, K. 2012, Manuscript in preparation.
Inorganic \& Coordination Chemistry

264

Luminescent cis- and trans- $\mathrm{N}$-Heterocyclic Carbene Platinum(II) Arylacetylide Complexes

Yuzhen Zhang, Olivier Blacque, Koushik Venkatesan*

Institute of Inorganic Chemistry, University of Zürich, Winterthurerstrasse 190, CH-8057, Zürich, Switzerland

Recently, we had reported the synthesis and luminescent properties of a series of $c i s$-bis- $N$-heterocyclic carbene platinum(II) bis-arylacetylide complexes. The complexes displayed room temperature phosphorescence and their emission properties could be tuned by varying the aryl functional groups. ${ }^{[1]}$

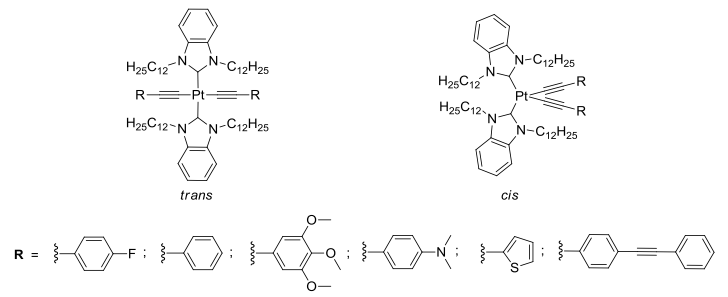

Following on these lines, structural and photophysical properties for a series of new cis- and trans- bis- $N$-heterocyclic carbene platinum(II) bis-arylacetylide complexes along with their mechanism of formation were investigated. In addition, mechanisitic insight into the cis-trans conversion is also proposed based on several experimental studies with support from DFT calculations. Both cis- and trans- complexes show room temperature phosphorescence emission both in solution and solid state. The high yielding synthesis of trans- complexes coupled with their tunable phosphorescence properties makes these molecules as interesting candidates for further exploration of their applications in the field of luminescent materials.

[1] Zhang, Y.; Garg, J.A.; Clement, M.; Fox, T.; Blacque, O.; Venkatesan, K Inorg. Chem. 2011, 50, 1220-1228.
Inorganic \& Coordination Chemistry

Enhancement in DNP-SENS: the Effect of Surface Functionalities in Hybrid Silica Materials

W. R. Grüning ${ }^{1}$, M. P. Conley ${ }^{1}$, D. Gajan ${ }^{1}$, A. Zagdoun ${ }^{2}$, A. J. Rossini ${ }^{2}$, G.

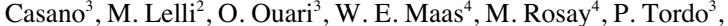
A. Lesage ${ }^{2}$, L. Emsley $^{2}$, C. Copéret

${ }^{1}$ ETH Zurich, Wolfgang-Pauli-Str. 10, 8093 Zurich, Switzerland. ${ }^{2}$ CRMN, Université de Lyon, 69100 Villeurbanne, France. ${ }^{3}$ SREP LCP UMR 6264, Univeristés d'Aix-Marseille, 13013 Marseille, France.

${ }^{4}$ Bruker BioSpin Corporation, Billerica, MA 01821, USA

Dynamic nuclear polarization surface enhanced NMR spectroscopy (DNPSENS) has been recently introduced as powerful technique to observe and characterize surface species in variety of materials including functionalized mesoporous silicates [1-2]. Here we discuss the effects of surface functionalization (FG) [3-4] and passivation (PG) on the observed enhancement factor $(\boldsymbol{\varepsilon})$ (Figure 1). a)

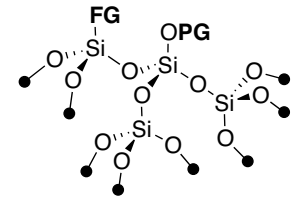

PG: D, $\mathrm{CH}_{3}, \mathrm{CD}_{3}$, TMS, TMS-d9

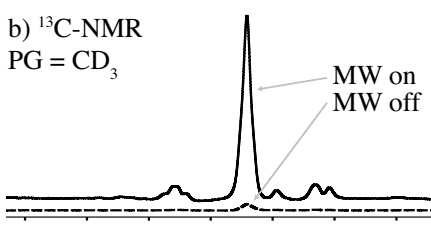

$\leftarrow \delta / \mathrm{ppm}$
Figure 1: a) Passivated functionalized silica; b) observed signal enhancement for deutero methyl passivated surface through DNP-SENS

[1] Lesage, A. et al., J. Am. Chem. Soc. 2010, 132, 15459

[2] Lelli, M. et al., J. Am. Chem. Soc. 2011, 133, 2104.

[3] Zagdoun, A. et al.,Chem. Commun. 2012, 48, 654.

[4] Zagdoun, A. et al., J. Am. Chem. Soc. 2012, 134, 2284.
Inorganic \& Coordination Chemistry

Selective Oxidation of Primary Alcohols with Vitamin K3

Vittorio Sacchetti, Friederike Tewes, Prof. Hansjörg Grützmacher

Laboratory of Inorganic Chemistry, Swiss Federal Institute of Technology, ETH Zürich, 8093 Zurich, Switzerland

Oxidations are among the most important reaction types in organic chemistry. Especially in the field of alcohol oxidations, a major progress from classical, mostly toxic and polluting reagents to more modern, environmentally friendly and inexpensive oxidation methods with $\mathrm{O}_{2}$ and $\mathrm{H}_{2} \mathrm{O}_{2}$ as terminal oxidants is observed. ${ }^{1,2}$

Previous work in this group showed that iridium-based catalysts are able to oxidize primary alcohols to the corresponding aldehydes. Most notably it was found that the catalyst $\left[\operatorname{Ir}\left(\operatorname{trop}_{2} \mathrm{DAD}\right] \mathrm{OTf}\right.$ (1) $($ tropDAD $=\mathrm{N}, \mathrm{N}$-bis $(5-\mathrm{H}$ dibenzo[ $a, d]$ cycloheptene-5-yl)-1,4-diazabuta-1,3-diene) in combination with p-benzoquinone as co-oxidant results in a highly active catalytic system for the dehydrogenation of alcohols. ${ }^{3,4}$
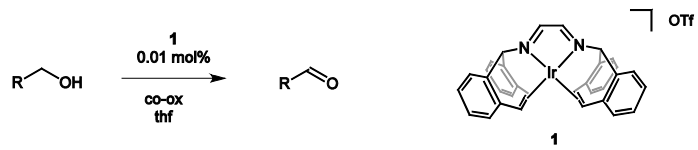

Recently, we found that vitamin K3 can act as hydrogen acceptor which provides milder reaction conditions for the oxidation of alcohols.

[1] J.E. Bäckvall, Modern Oxidation Methods, Wiley-VCH Verlag GmbH \& $\mathrm{Co}, 2005$

[2] I.W.C.E. Arends, R. A. Sheldon, in Modern Oxidation Methods, Wiley-VCH Verlag GmbH \& Co, 2005, pp. 83-118.

[3] M. Königsmann, N. Donati, D. Stein, H. Schönberg, J. Harmer, A. Sreekanth, H. Grützmacher, Angew. Chem. Int. Ed. 2007, 46, 3567.

[4] F. Tewes, ETH Dissertation No. 18705, 2009. 
Inorganic \& Coordination Chemistry

Diolefin Diamide Rhodium(I) Complex and Its one Electron Oxidation Resulting in a 2 center 3 electron Rhodium-Nitrogen bond.

$\underline{\text { Amos J. Rosenthal }}^{1}$, Matthias Vogt ${ }^{1}$, Bas de Bruin ${ }^{2}$, Hansjörg Grützmacher ${ }^{1}$

${ }^{1}$ Laboratory of Inorganic Chemistry, Swiss Federal Institute of Technology, ETH Zürich, 8093 Zurich, Switzerland

${ }^{2}$ Universiteit van Amsterdam, Faculty of Science, 1098 XH Amsterdam. The Netherlands

Amide complexes of late transition metals hold particularly important roles in biological processes. ${ }^{[1]}$ It has been established that the catalytic activity of metalloenzymes is based on the activity of the central metal ion and thus on the nature of the bonds to the ancillary ligands. ${ }^{[2]}$ Therefore, understanding the nature of the M-N bond is important.

Recently, we have observed that in the penta coordinate rhodium complex 1 $\left(\left[\mathrm{Rh}(\mathrm{I})\left(\operatorname{trop}_{2} \mathrm{~N}\right)(\text { bipy) }]^{+}\right.\right.$(where trop is 5-H-dibenzo[a,d]cycloheptene-5-yl)), which is best described as an aminyl radical species stabilized through coordination to a rhodium(I) center. ${ }^{[3]}$

In the present study, we describe the synthesis and characterization of a stable anionic trans diamido rhodium(I) complex 2 and its oxidation to the neutral complex $\mathbf{3}$. The latter paramagnetic complex $\mathbf{3}$ contains a remarkably stable 2 center 3 electron bond.

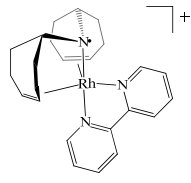

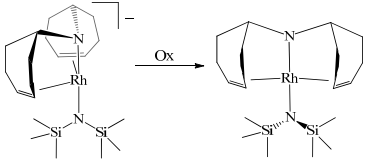

[1] R. H. Holm, P. Kennepohl, E. I. Solomon, Chem. Rev. 1996, 96, 2239.

[2] J. Stubbe, W. A. van der Donk, Chemical Reviews 1998, 98, 705.

[3] T. Buttner, J. Geier, G. Frison, J. Harmer, C. Calle, A. Schweiger, H. Schonberg, H. Grützmacher, Science 2005, 307, 235.
Inorganic \& Coordination Chemistry

\section{Formation of the reverse splice site in group II intron retrohoming}

\section{Miriam Skilandat, Roland K. O. Sigel}

University of Zurich, Institute for Inorganic Chemistry, Winterthurerstrasse 190, 8057 Zurich, Switzerland

Group II introns are large RNA molecules encoded in bacterial and eukaryotic organellar genomes. In presence of Magnesium(II), group II introns can catalyze their own excision from an RNA transcript and ligation of the flanking regions, a process referred to as splicing. The reverse process; the reinsertion of the intron into DNA strands [1], termed retrohoming, can also be performed by the intron. Retrohoming events are not harmful to the host organism since they are confined to specific sites in the genome. This is achieved by basepairing of the exon-binding sites 1-2 of the intron (EBS1-2) to complementary intron-binding sequences on the target strand (IBS1-2).

To better understand molecular recognition in retrohoming events and the importance of $\mathrm{Mg}(\mathrm{II})$, we investigated by NMR spectroscopy a minimal model of a reverse splice site comprising the EBS1-containing RNA hairpin and the dIBS1 DNA 7-mer directly upstream of the splice site, where the DNA strand is opened for reinsertion. The solution structure was solved and four metal-ion binding sites were identified from $\mathrm{Mg}$ (II)-, $\mathrm{Mn}$ (II)- and cobalt(III) hexammine titrations. One of these suggested binding sites is located close to the splice site and might harbour a catalytically relevant $\mathrm{Mg}$ (II)-ion [2]. Using Surface Plasmon Resonance experiments, we could further show that the presence of $\mathrm{Mg}$ (II) strongly increases the inherently low affinity of dIBS1 for EBS1.

Financial support by the Swiss National Science Foundation and the University of Zurich is gratefully acknowledged.

[1] S. Zimmerly, H. Guo, R. Eskes, J. Yang, P. S. Perlman, A. M. Lambowitz, Cell 1995 $83,529-538$

[2] R. K. O. Sigel, A. Vaidya, A. M. Pyle Nature Struct. Biol. 2000, 7, 1111-1116.
Inorganic \& Coordination Chemistry

Solution NMR studies demonstrate the stabilization of the group II intron core by di- and trivalent metal ions

Maria Pechlaner, Daniela Donghi and Roland K.O. Sigel

Institute of Inorganic Chemistry, University of Zurich, Winterthurerstrasse 190, 8057 Zurich

Group II introns are self-splicing ribozymes. They excise from RNA, but can also reinsert into RNA or DNA, thus acting as mobile genetic elements [1] Their folding and catalytic mechanism is dependent on divalent metal ions [2]. At the core of those large, multidomain RNAs is a small region that serves as folding control element [3] and contains two conserved motifs: $\kappa$ (embedded in a three-way junction) and $\zeta$ (a tetraloop receptor motif).

We have solved the solution structure in the presence of $\mathrm{Mg}^{2+}$ of a $49 \mathrm{nu}$ cleotide construct containing the $\kappa$ and $\zeta$ region of S.cerevisiae group II intron Sc.ai5 $\gamma$ by NMR. Like the complete intron, which does not fold into its compact active state without $\mathrm{Mg}^{2+}$ [4], also this small subdomain does not form a stable structure in the absence of divalent metal ions. We can show that $\mathrm{Cd}^{2+}$ and cobalt(III)hexamine both are able to promote the stabilization of the three-way junction in a similar way as the natural co-factor $\mathrm{Mg}^{2+}$, while high amounts of $\mathrm{K}^{+}$are not sufficient.

Financial support by the Swiss National Science Foundation and the University of Zurich is gratefully acknowledged.

[1] Lehmann K. and Schmidt U., Critical Rev. Biochem. Mol. Biol. 2003, $38,249$.

[2] Sigel R.K.O., Eur. J. Inorg. Chem. 2005, 2005, 2281.

[3] Waldsich C. and Pyle A.M., Nat. Struct. Mol. Biol. 2007, 14, 37.

[4] Pyle A.M., Fedorova O. and Waldsich C., Trends Biochem. Sci. 2007, 32,138
Inorganic \& Coordination Chemistry

The kinetics of the interaction between the $b t u B$ riboswitch and coenzyme $B_{12}$

Pallavi Choudhary and Roland K. O. Sigel

University of Zürich, Institute of Inorganic Chemistry, Winterthurerstrasse 190, 8057 Zürich

Riboswitches are small conserved sequences in the 5'-untranslated region of bacterial mRNA that bind certain metabolites with high affinity and specificity. The 202 nucleotide long btuB riboswitch of E.coli undergoes a structural rearrangement upon interaction with coenzyme $\mathrm{B}_{12}$ and some of its derivatives [1-3]. Although being one of the earliest reported riboswitches, little is known about the mechanism of interaction between the $b t u B$ riboswitch and its ligand.

To get into the details of the interaction between the $b t u B$ riboswitch and coenzyme $B_{12}$, we applied the surface plasmon resonance (SPR) spectroscopy. With the help of SPR, we were able to measure the association and dissociation constants of the btuB-coenzyme $\mathrm{B}_{12}$ system. Moreover, the comparison of the kinetic constants has also revealed that the slow rate of dissociation makes coenzyme $\mathrm{B}_{12}$ bind stronger to the btuB riboswitch compared to a related ligand, Vitamin $\mathrm{B}_{12}$.

Financial support by the Swiss National Science Foundation and the European Research council (ERC starting grant) is gratefully acknowledged. [1] A. Nahvi, N. Sudarsan, M. S. Ebert, X. Zou, K. L. Brown, R. R. Breaker, Chem. Biol. 2002, 9, 1043

[2] S. Gallo, M. Oberhuber, R. K. O. Sigel, B. Kräutler, ChemBioChem. 2008, 9, 1408

[3] S. Gallo, S. Mundwiler, R. Alberto, R. K. O. Sigel, Chem. Commun. 2011, 47, 403-405. 
Inorganic \& Coordination Chemistry

Comparison of $b t u B$ riboswitche variants by single molecule FRET studies

Michelle F. Schaffer and Roland K.O. Sigel

Institute of Inorganic Chemistry, University of Zürich, Winterthurerstrasse 190, CH-8057 Zürich michelle.schaffer@uzh.ch

Riboswitches are complex folded RNA domains in the 5'-untranslated region of bacterial mRNA that serve as specific receptors for metabolites. Conformational changes of the 202nt long btuB riboswitch of E.coli induced by coenzyme $\mathrm{B}_{12}$ (AdoCbl) and some of its derivatives lead to an altered gene expression of the downstream $b t u B$ gene [1]. The interaction of the riboswitch with its ligand strongly depends on the initial tertiary structure of the RNA and is affected by $\mathrm{Mg}^{2+}$ ions, but the folding pathway still remains mostly unclear.

Therefore, we investigate the folding pathway of the $b t u B$ riboswitch upon addition of $\mathrm{Mg}^{2+}$ to characterise the initial conditions needed for coenzyme $\mathrm{B}_{12}$ binding to the riboswitch.

In our study, we focus on single molecule Förster Resonance Energy Transfer (smFRET) measurements [2]. For successful FRET studies it is crucial to find an optimal position for labelling of a large RNA. Hence, we created four different constructs with modified internal loops and extended 3'- and 5 '-ends to attach a pair of fluorophore-labelled DNA-oligonucleotides (Cy3 and Cy5). FRET allows us then to monitor the interdomain movements of the $b t u B$ riboswitch and to study the effects of $\mathrm{Mg}^{2+}$ ions on its folding.

Financial support by the University of Zürich and the European Research council (ERC starting grant) is gratefully acknowledged.

[1] X. Nou, R.J. Kadner, Proc. Natl. Acad. Sci. USA 97, 7190 (2000)

[2] L.Cardo, K.S.Karunalilaka, D.Rueda, R.K.O Sigel, Methods Mol. Biol. 848,227 (2009)
Inorganic \& Coordination Chemistry

Charge transfer through metal-modified nucleic acids

Bhaumik Dave, Silke Johannsen, Roland K. O. Sigel

Institute of Inorganic Chemistry, University of Zurich, Winterthurerstrasse 190, 8057 Zurich

Application of nucleic acids as building blocks of nano-scale molecular wires takes into consideration the superb self-assembly properties along with their well-defined structural features. Recently, a method for incorporating metal-ions within the structural frame work of nucleic acids in a predictable manner has been established using metal-mediated base pairs. ${ }^{[1]}$ We aim to set-up charge-transfer experiments of metal-modified RNA by using the well-known DNA light-switch complex $\left[\mathrm{Ru}(\mathrm{bpy})_{2}(\mathrm{dppz})\right]^{2+}$. RNA sequences with 2, 3 and 6 consecutive uracil-uracil miss-matched base pairs were transcribed that upon addition of $\mathrm{Hg}^{\mathrm{II}}$ ions, form $\mathrm{U}-\mathrm{Hg}-\mathrm{U}$ base pairs (see Figure). ${ }^{[2]}$ To investigate the thermal stability of the metal-modified RNA sequences upon intercalation, UV melting studies were carried out. Using absorption and emission experiments, we characterize the intercalation of $[\mathrm{Ru}(\mathrm{bpy}) 2(\mathrm{dppz})]^{2+}$ into our RNA duplexes to reveal exact binding affinities in the presence and absence of $\mathrm{Hg}^{\text {II }}$ ions. Additional NMR experiments will help to confirm the intercalation.
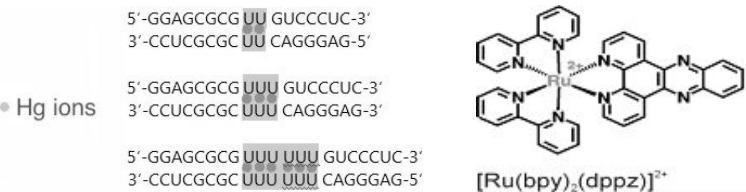

$\left[R u(b p y)_{2}(d p p z)\right]^{2+}$

Financial support by the Swiss National Science Foundation and the University of Zurich is gratefully acknowledged.

[1] K. Tanaka; M. Shionoya, J. Org. Chem. 1999, 64, 5002-5003.

[2] S. Johannsen; S. Paulus; N. Düpre; J. Müller; R. K. O. Sigel, J. Inorg Biochem. 2008, 102, 1141-1151.
Inorganic \& Coordination Chemistry

RNA: an additional target for platinum based anticancer drugs?

\section{Dania Marthaler, Daniela Donghi}

Institute of Inorganic Chemistry, University of Zurich, Winterthurerstrasse 190, CH-8057, Zurich, Switzerland

Cellular DNA is recognized as the major biological target for the metalbased anticancer drugs cisplatin and its derivatives [1]. However, it is important to understand the interaction of such drugs with molecular targets other than DNA to comprehend their side effects, their tumor resistance as well as to better characterize their mechanisms of action. Although RNA is involved in manifold biological processes, only little is known on its interaction with metal-based anticancer drugs [2].

We are currently investigating the behavior of an RNA hairpin upon addition of cisplatin and its derivatives. Our model RNA is the truncated domain 6 of the mitochondrial group II intron $S c$.ai5 $\gamma$, from baker's yeast, whose solution structure is known [3]. The platinated RNA molecules are analyzed by means of biochemical techniques as well as NMR spectroscopy, to evaluate sequence and structure preferences of the binding.

Financial support by Swiss National Science Foundation (Ambizione fellowship PZ00P2_136726 to DD) as well as by the University of Zurich is gratefully acknowledged.

[1] See for example B. Lippert, Cisplatin, Chemistry and Biochemistry of a Leading Anticancer Drug, 1999, Wiley-VCH, Weinheim, Germany.

[2] See for example E.G. Chapman, V.J. DeRose, J. Am. Chem. Soc., 2010, 132, 1946; K. Rijal, C.S. Chow, Chem. Commun., 2009, 107; P. Papsai, A.S. Snygg, J. Aldag, S.K.C. Elmroth, Dalton Trans., 2008, 2552.

[3] M.C. Erat, O. Zerbe, T. Fox, R.K.O. Sigel, ChemBioChem 2007, 8, 306.
Inorganic \& Coordination Chemistry

\section{Tumor Uptake of Vitamin B12 Prodrugs}

Mai Thanh Quynh Tran ${ }^{1}$, Stefan Stürup ${ }^{2}$, Ian Henry Lambert ${ }^{3}$, Roger Alberto ${ }^{1}$

${ }^{1}$ University of Zürich / Institute of Inorganic Chemistry Winterthurerstrasse 190, CH-8057 Zürich, Switzerland ${ }^{2}$ University of Copenhagen / Faculty of Health Sciences, Department of Pharmaceutics and Analytical Chemistry

Universitetsparken 2, DK-2100 Copenhagen, Denmark

${ }^{3}$ University of Copenhagen / Department of Biology

Universitetsparken 13, DK-2100 Copenhagen, Denmark

The upregulation of transcobalamin receptors for the uptake of cobalamin (in the mixture with its transport protein) is the basis for targeting tumors with vitamin $B_{12}(\mathbf{1})$ both in cancer diagnosis and therapy. ${ }^{[1]}$ Vitamin $B_{12}$ was showed to form stable complexes with cisplatin and other platinated compounds. ${ }^{[2]}$ We present here a new strategy to attach non-metal anticancer drugs to platinated $B_{12}(2)$. In addition, the uptake of vitamin $B_{12}$ prodrugs is presented for various cell lines. The ability of vitamin $B_{12}$ to form stable complexes with different anticancer drugs and its delivery efficiency are discussed.

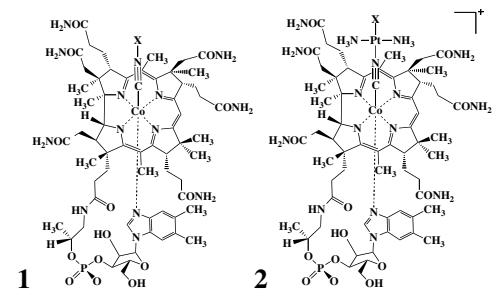

$\mathrm{X}=$ Anticancer drugs

[1] T. Amagasaki et al., Blood, 1990, 76, 1380.

[2] P. R. Sanchéz et al., J. Biol. Inorg. Chem., 2008, 13, 335. 
Inorganic \& Coordination Chemistry

\section{$\left[(\mathrm{Cp}-\mathrm{R}) \mathrm{M}(\mathrm{CO})_{3}\right]\left(\mathrm{M}=\mathrm{Re}\right.$ or $\left.{ }^{99 \mathrm{~m}} \mathrm{Tc}\right)$ Conjugates for Selective Targeting of Human Carbonic Anhydrase IX}

$\underline{\text { Daniel Can }}{ }^{1}$, Bernhard Spingler ${ }^{1}$, Isabel Santos ${ }^{2}$, Claudiu T. Supuran ${ }^{3}$ and Roger Alberto ${ }^{1}$

${ }^{1}$ ACI, University of Zurich, Winterthurerstrasse 190, 8057 Zurich, CH ${ }^{2}$ ITN, Estrada Nacional 10, 2686-953 Sacavém, PT

${ }^{3}$ UNIFI, Laboratorio di Chim-iCABioinorganica, 50019 Sesto Fiorentino, IT

Organometallic complexes with bioactive ligands are nowadays interesting for both, the noninvasive imaging of biological features and the therapeutic treatment of diseases. While several transition metals across the periodic table are frequently used for therapy, ${ }^{99 \mathrm{~m}} \mathrm{Tc}$ is the most prominent nuclide in nuclear medicine.[1] Carbonic anhydrases catalyze the conversion of $\mathrm{CO}_{2}$ to the bicarbonate ion and protons. The expression of CA IX in tumors is associated with poor prognosis, tumor progression and aggressiveness, suggesting that CA IX may be a good therapeutic and radiopharmaceutical target.[2] However, the large number of isozymes and diffuse localization impede selective accumulation of inhibitors.[2] Meggers et al. outlined with protein kinase inhibitors that organometallic complexes, as compared to organic compounds, can have the property of enhanced three dimensional population of chemically relevant biological space, such as binding cavities of proteins.[3] Such molecules therefore can achieve high selectivity for specific targets. We lately demonstrated with organometallic carbonic anhydrase inhibitors, that compounds containing $[(\mathrm{Cp}) \operatorname{Re}(\mathrm{CO}) 3]$ truly follow this concept.[4] Synthesis of the $\left[(\mathrm{Cp}) \mathrm{M}(\mathrm{CO})_{3}\right]$ - complexes $\left(\mathrm{M}=\mathrm{Re}\right.$ or $\left.{ }^{{ }^{99} \mathrm{~m}} \mathrm{Tc}\right)$ and their biological evaluation are in the focus of this work.

[1] R. Alberto, in Bioinorganic Medicinal Chemistry (Ed.: E. Alessio), WileyVCH, Weinheim, 2011, pp. 253-282.

[2] C. T. Supuran, Nature, 2008, 7, 168

[3] E. Meggers, Angew. Chem., Int. Ed. 2011, 50, 2442-2448.

[4] D. Can, B. Spingler, P. Schmutz, F. Mendes, P. Raposinho, C. Fernandes, F. Carta, A. Innocenti, I. Santos, C. T. Supuran, R. Alberto, Angew. Chem., Int. Ed. 2012, 51, 3354-3357.

Inorganic \& Coordination Chemistry

Synthesis and biological evaluation of ${ }^{99} \mathrm{~m}$ Tc-labeled cyclic RGD peptide with a tripod chelator

Yunjun Shen, ${ }^{\text {a }}$ Margret Schottelius, ${ }^{\mathrm{b}}$ Roger Alberto ${ }^{\mathrm{a}^{*}}$

${ }^{a}$ Institute of Inorganic Chemistry, University of Zürich, Winterthurerstr. 190,CH-8057 Zürich, Switzerland

${ }^{b}$ Nuklearmedizinische Klinik und Poliklinik, Klinikum rechts der Isar, TU München, Ismaningerstr. 22, 81675 München, Germany

Tumor-induced angiogenesis can be blocked in vivo by antagonizing the $\alpha_{v} \beta_{3}$ integrin with small peptides containing the Arg-Gly-Asp(RGD) amino acid sequence. Because of selective overexpression of $\alpha_{v} \beta_{3}$ integrin in tumors, radiolabeled RGD peptides are attractive candidates for $\alpha_{\mathrm{v}} \beta_{3}$ integrin targeting in tumors[1]. In this study, we report the design and development of a new cyclic RGD analogue $c y c l o(A r g-G l y-A s p-D-T y r-L y s(D A P))$ that can be radiolabeled with the $\left.{ }^{99 \mathrm{~m}} \mathrm{Tc}\left(\mathrm{OH}_{2}\right)_{3}(\mathrm{CO})_{3}\right]^{+}$complex. The novel cyclic $\mathrm{RGD}($ Lys DAP) peptide was prepared with an orthogonally protected lysine derivative, containing at its $\varepsilon$-position 1,2-diaminopropionic acid as a strong tripod chelator for the $\left[{ }^{99 \mathrm{~m}} \mathrm{Tc}(\mathrm{CO})_{3}\right]^{+}$core[2][3]. The labeling of cyclic RGD analogue with $\left[{ }^{99 \mathrm{~m}} \mathrm{Tc}\left(\mathrm{OH}_{2}\right)_{3}(\mathrm{CO})_{3}\right]^{+}$was achieved in very good yield $(>99 \%)$. The $\mathrm{IC}_{50}$ for $\alpha_{\mathrm{v}} \beta_{3}$ is $7.1 \mathrm{nM}$ as compared to $3.1 \mathrm{nM}$ for native RGD. A biodistribution showed reasonable tumor uptake which could be blocked by the competing peptide cilengitide.

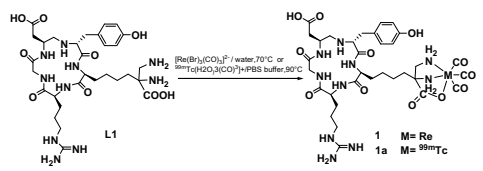

[1] Clemens D, Haubner R, et al. Nucl.Med.Biol. 2006, 33, 945

[2] Liu Y, Alberto R, et al. J Am Chem Soc. 2006,128,15996

[3] Liu Y, Alberto R, et al. Org.Biomol.Chem. 2010, 8, 2829
Inorganic \& Coordination Chemistry

\section{Novel Approaches for the Synthesis of high-valent $\mathrm{fac}_{-}\left\{{ }^{99(\mathrm{~m})} \mathrm{TcO}_{3}\right\}^{+}$ Complexes and their Reactivity with Alkynes}

Michael Benz, Sebastian Imstepf, Henrik Braband, Roger Alberto

University of Zurich, Winterthurerstrasse 190, 8057 Zurich, Switzerland

In analogy to $\left[\mathrm{OsO}_{4}\right]$ and $\left[\mathrm{RuO}_{4}\right]$, complexes containing the high-valent fac$\left\{{ }^{99(\mathrm{~m})} \mathrm{TcO}_{3}\right\}^{+}$core undergo metal-mediated, vicinal cis-dihydroxylation reactions with alkenes $((3+2)$-cycloaddition $) .{ }^{[1]}$ On the basis of this reactivity fac- $\left\{{ }^{99 \mathrm{~m}} \mathrm{TcO}_{3}\right\}^{+}$complexes have been established as precursors for a new labeling strategy for radiopharmaceutical applications. ${ }^{[2]}$ However, water stable $f a c-\left\{{ }^{99(\mathrm{~m})} \mathrm{TcO}_{3}\right\}$ complexes are rare and possibilities for their synthesis limited. Therefore, we report novel synthetic procedures for the synthesis of water stable $f a c-\left\{{ }^{99(\mathrm{~m})} \mathrm{TcO}_{3}\right\}^{+}$complexes. These reactions led to the first negatively charged $\mathrm{fac}_{-}\left\{{ }^{99} \mathrm{TcO}_{3}\right\}$ complex, $\left[{ }^{99} \mathrm{TcO}_{3}(\text { nota })\right]^{2-}\left(\right.$ nota $=2,2^{\prime}, 2^{\prime \prime}$ (1,4,7-triazonane-1,4,7-triyl)triacetate). This complex has been prepared by oxidation of a low-valent $f a c-\left\{{ }^{99} \mathrm{Tc}(\mathrm{CO})_{3}\right\}^{+}$precursor with sodium perborate tetrahydrate $\left(\mathrm{NaBO}_{3} \cdot 4 \mathrm{H}_{2} \mathrm{O}\right){ }^{[3]}$

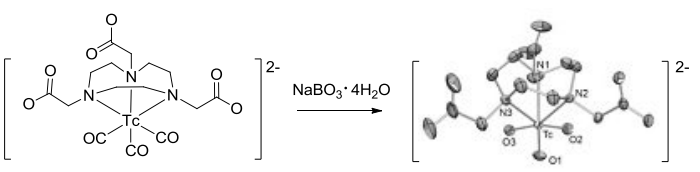

Recently, alkynes gained much interest in drug development ('click chemistry'). In the context of the new labeling strategy (vicinal cisdihydroxylation reactions with stable $f a c-\left\{{ }^{99 \mathrm{~m}} \mathrm{TcO}_{3}\right\}^{+}$) alkynes are a logical extension as substrates. Therefore, we report the first reactions of the model complex $\left[{ }^{99} \mathrm{TcO}_{3}(\operatorname{tacn})\right]^{+}$with different alkynes.

[1] Pearlstein, R. M.; Davison, A., Polyhedron 1988, 7, 1981-1989

[2] Braband, H.; Tooyama, Y.; Fox, T.; Simms, R.; Forbes,J.; Valliant, J.F.; Alberto, R., Chem. Eur. J. 2011, 17, 12967.

[3] Braband, H.; Imstepf, S.; Benz, M.; Spingler, B.; Alberto, R. Inorg. Chem. 2012 51, 4051-4057.

Probing of the metallation-process from the $\mathrm{Zn}^{\mathrm{II}}$ - to the $\mathrm{Cd}^{\mathrm{II}}$-form of the $\gamma-E_{c}-1$ metallothionein by NMR spectroscopy

\section{Silke Johannsen, Jens Loebus, Eva Freisinger}

Institute of Inorganic Chemistry, University of Zurich, Winterthurerstrasse 190, 8057 Zurich

The smaller $\gamma$-domain of the plant metallthionein (MT) $\mathrm{E}_{\mathrm{c}}-1$ from Triticum aestivum forms a $\mathrm{M}_{2} \mathrm{Cys}_{6}$ cluster in the presence of essential $\mathrm{Zn}^{\mathrm{II}}$ and toxic $\mathrm{Cd}^{\mathrm{II}}$. The NMR solution structures of $\mathrm{Zn}_{2-}$ and $\mathrm{Cd}_{2}-\gamma-\mathrm{E}_{\mathrm{c}}-1$ reveal a highly dynamic metal cluster, switching between two cysteines as second bridging thiolate ligand.[1] As this is the smallest feasible cluster arrangement, further characterisation of this cluster is not only important for a better understanding of structure and function of metallothioneins (MTs), but the $\gamma$ domain is also an ideal model compound to probe metallation and demetallation processes of metal-thiolate clusters in general.

To investigate the specific binding properties of the two metallation sites (A and $B$ ) the stepwise addition of ${ }^{113} \mathrm{Cd}^{\mathrm{II}}$ ions to $\mathrm{Zn}_{2}-\gamma-\mathrm{E}_{\mathrm{c}}-1$ was followed by ${ }^{1} \mathrm{H}$ and ${ }^{113} \mathrm{Cd}$ NMR spectroscopy. The ${ }^{1} \mathrm{H},{ }^{1} \mathrm{H}$ TOCSY and ${ }^{1} \mathrm{H},{ }^{113} \mathrm{Cd}$ HSQC spectra nicely show that all four possible metal species $\left(\mathrm{Zn}_{2}\right.$, $\mathrm{Cd}(\mathrm{A}) \mathrm{Zn}(\mathrm{B}), \mathrm{Zn}(\mathrm{B}) \mathrm{Cd}(\mathrm{A})$ and $\left.\mathrm{Cd}_{2}\right)$ coexist and are in slow exchange. Using the TOCSY and ${ }^{1} \mathrm{H},{ }^{113} \mathrm{Cd} \mathrm{HSQC}$ spectra all species were unambiguously identified and the abundance was quantified. Interestingly, we observed a cadmium specificity of the metal-binding site A upon exposure of the fully metallated $\mathrm{Zn}_{2}-\gamma-\mathrm{E}_{\mathrm{c}}-1$ to $\mathrm{Cd}^{\mathrm{II}}$ ions. This implies a metallation-pathway with the $\mathrm{Cd}(\mathrm{A}) \mathrm{Zn}(\mathrm{B})$ form as the main intermediate $(\sim 75 \%)$.

Financial support from the Swiss National Science Foundation (Marie-Heim Vögtlin Fellowship to SJ and SNSF-Professorship PP002-119106/1 to EF) and the University of Zurich are gratefully acknowledged

[1] J. Loebus, E.A. Peroza, N. Blüthgen, T. Fox, W. Meyer-Klaucke, O. Zerbe, E. Freisinger, J. Biol. Inorg. Chem. 2011, 16, 683. 
Inorganic \& Coordination Chemistry

$\mathrm{RbCoCl}_{3}$ - an Ising Chain Compound

$\underline{\text { Nora Hänni }^{1}}{ }$, Christian Rüegg ${ }^{2}$, Karl Krämer ${ }^{1}$

${ }^{1}$ University of Bern, Freiestrasse 3, CH-3012 Bern, Switzerland ${ }^{2}$ Paul Scherrer Institute, CH-5232 Villigen, Switzerland

The hexagonal perovskite type compound $\mathrm{RbCoCl}_{3}$ is a good realization of an antiferromagnetic Ising chain, which is mostly due to the strong single ion anisotropy of the high-spin $\mathrm{Co}^{2+}$ ion. Despite investigations of this compound during the last decades [1-3], questions remain to be answered. Hence we focus on the investigation of the temperature dependence of both the crystal structure and the magnetic structure of $\mathrm{RbCoCl}_{3}$ for the first time by means of neutron diffraction.

In a series of powder and single crystal neutron diffraction experiments performed at the Swiss Spallation Neutron Source (SINQ) at Paul Scherrer Institute, we were able to confirm the crystal structure and to disentangle the magnetic structure of $\mathrm{RbCoCl}_{3}$. As expected from literature, $\mathrm{RbCoCl}_{3}$ does not undergo structural phase transitions down to liquid helium temperature and the hexagonal symmetry (space group $\mathrm{P}_{3} / \mathrm{mmc}$ ) is conserved. Its magnetic structure, however, was found to be slightly different than proposed for isostructural compounds [4]. The neutron diffraction data is in good agreement with information obtained from subsidiary magnetic susceptibility and specific heat measurements.

[1] Å. Engberg, H. Soling, Acta chem. Scand. 1967, 21, 168.

[2] F. Matsubara, S. Inawashiro, H. Ohhara, J. Phys. Condens. Mat. 1991, $3,12,1815$.

[3] G. A. Petrakovskii, N. V. Fedoseeva, S. S. Alpesnin, V. K. Korolev, Fiz. Tverd. Tela 1989, 31, 8, 169.

[4] J. P. Goff, D. A. Tennant, S. E. Nagler, Phys. Rev. B 1995, 52, 22, 15992. 